Article

\title{
Consumption of Atmospheric Carbon Dioxide through Weathering of Ultramafic Rocks in the Voltri Massif (Italy): Quantification of the Process and Global Implications
}

\author{
Francesco Frondini ${ }^{1, *} \mathbb{1}$, Orlando Vaselli ${ }^{2}$ and Marino Vetuschi Zuccolini ${ }^{3}$ \\ 1 Dipartimento di Fisica e Geologia, Università degli Studi di Perugia, Via Pascoli s.n.c., 06123 Perugia, Italy \\ 2 Dipartimento di Scienze della Terra, Università degli Studi di Firenze, Via La Pira 4, 50121 Firenze, Italy; \\ orlando.vaselli@unifi.it \\ 3 Dipartimento di Scienze della Terra dell'Ambiente e della Vita, Università degli Studi di Genova, \\ Corso Europa 26, 16132 Genova, Italy; zucco@dipteris.unige.it \\ * Correspondence: francesco.frondini@unipg.it
}

Received: 1 May 2019; Accepted: 5 June 2019; Published: 9 June 2019

\begin{abstract}
Chemical weathering is the main natural mechanism limiting the atmospheric carbon dioxide levels on geologic time scales ( $>1 \mathrm{Ma}$ ) but its role on shorter time scales is still debated, highlighting the need for an increase of knowledge about the relationships between chemical weathering and atmospheric $\mathrm{CO}_{2}$ consumption. A reliable approach to study the weathering reactions is the quantification of the mass fluxes in and out of mono lithology watershed systems. In this work the chemical weathering and atmospheric carbon dioxide consumption of ultramafic rocks have been studied through a detailed geochemical mass balance of three watershed systems located in the metaophiolitic complex of the Voltri Massif (Italy). Results show that the rates of carbon dioxide consumption of the study area (weighted average $=3.02 \pm 1.67 \times 10^{5} \mathrm{~mol} \mathrm{~km}^{-2} \mathrm{y}^{-1}$ ) are higher than the world average $\mathrm{CO}_{2}$ consumption rate and are well correlated with runoff, probably the stronger weathering controlling factor. Computed values are very close to the global average of basic and ultrabasic magmatic rocks, suggesting that Voltri Massif is a good proxy for the study of the feedbacks between chemical weathering, $\mathrm{CO}_{2}$ consumption, and climate change at a global scale.
\end{abstract}

Keywords: chemical weathering; ophiolites; carbon dioxide; geologic carbon cycle

\section{Introduction}

Weathering is a key process for understanding the global carbon cycle and its relations with climate [1-6]. The role of weathering on $\mathrm{CO}_{2}$ concentration in atmosphere is different if we consider times shorter or longer than a conventional limit of $1 \mathrm{Ma}$, roughly corresponding to the residence time of $\mathrm{Ca}$ in the ocean [7]. On the long-term $(>1 \mathrm{Ma})$, weathering is certainly the main natural mechanism limiting the atmospheric carbon dioxide levels, that primarily depend on the balance between $\mathrm{CO}_{2}$ uptake by chemical weathering and $\mathrm{CO}_{2}$ release by volcanism and metamorphism [8]. On short time scales $(<1 \mathrm{Ma})$ the role of chemical weathering is generally underrated; for example, most of the future climate models do not take chemical weathering into account, thus implicitly considering the $\mathrm{CO}_{2}$ consumption because weathering as an inert flux completely balanced by volcanic-metamorphic $\mathrm{CO}_{2}$ degassing. In contrast, recent studies have shown some clear evidences of the feedback between climate change and weathering rates, suggesting that chemical weathering is highly sensitive to climate change $[5,9,10]$. A recent study [11] demonstrated that the Mackenzie River basin, one of the biggest Arctic watersheds located in North-West Canada, respond to the increase of atmospheric carbon 
dioxide by capturing more atmospheric $\mathrm{CO}_{2}$ through chemical weathering (higher temperatures and rainfall accelerate mineral dissolution). We are still unaware of what is the response of weathering to climate change at a global scale but it is clear that chemical weathering is also playing a significant role in the short-term global carbon cycle and the mechanism of $\mathrm{CO}_{2}$ consumption by chemical weathering should be considered in the future models of climate change [11].

One of the most reliable ways of studying weathering reactions in natural settings is the quantification of the mass fluxes into and out of watershed systems [12-17]. Natural chemical weathering rates can be computed through accurate geochemical mass balances of river systems following two complementary approaches: (i) the study of large river systems, that are currently used for the estimation of the $\mathrm{CO}_{2}$ consumption by weathering at a global scale [15-23]; (ii) the study of small mono lithology river basins that can give more accurate estimations of the chemical weathering rates and their controlling parameters in natural settings [24-28].

The knowledge of the relationships between natural chemical weathering rates and controlling parameters (e.g., temperature, precipitation, infiltration, runoff) can help to clarify the discrepancy observed between field and laboratory data [28-32] and could allow the up-scaling of local measurements to a global scale, contributing to the refinement of global $\mathrm{CO}_{2}$ consumption estimations. Furthermore, study of the parameters controlling weathering rates in natural settings can improve the knowledge of the feedback between climate and weathering and its role on short-term carbon cycle and climate change $[10,11,23]$.

The weathering of calcium and magnesium silicates is the main geologic mechanism naturally limiting atmospheric $\mathrm{CO}_{2}$ levels. The weathering process transforms $\mathrm{CO}_{2}$ into bicarbonate, that in the long term (time $>1 \mathrm{Ma}$ ) precipitates as $\mathrm{Ca}$ and $\mathrm{Mg}$ carbonate in the oceans. Ultramafic rocks, almost completely composed by $\mathrm{Mg}$, $\mathrm{Fe}$, and Ca silicates, are the rocks with the highest potential for the removal of $\mathrm{CO}_{2}$ from the atmosphere-hydrosphere system and their alteration process significantly affected the evolution of the Earth's atmosphere [33] and continental crust through geological times [34]. Despite the interest on ultramafic rocks for their potential use in the field of mineral carbonation $[35,36]$ and their importance for the study of the atmospheric evolution, the rate of $\mathrm{CO}_{2}$ uptake via weathering of peridotite and serpentinite is still poorly known in natural conditions [37].

In this work we investigate the chemical weathering of ultramafic rocks through the geochemical and isotopic study of three small rivers whose drainage basins are almost completely composed of the ultramafic rocks of the Voltri Massif, Western Alps-Northern Italy (Figure 1). The main objectives of the work are (1) to estimate the natural chemical weathering rates, (2) to determine the rates of atmospheric $\mathrm{CO}_{2}$ consumption related to chemical weathering, (3) to study the control exerted by runoff, temperature, and other potential controlling factors on chemical weathering rates of ultramafic rocks, and (4) to compare our results to the global estimations of $\mathrm{CO}_{2}$ consumption rates.

\section{Study Area}

The study area is located in the Ligurian Alps few kilometers west of the city of Genoa (Northern Italy) where the southern part of the Western Alps leave place to Appennines. It is bordered to the south by the steep continental margin of the Liguro-Provençal Basin and to the north by the Neogene thick sedimentary prism of the Po Plain (Figure 1a).

The geology of the area is dominated by the Voltri Massif, a $30 \mathrm{~km}$ wide, E-W elongated tectono-metamorphic unit [38,39]. The Voltri Massif, which has in the M. Beigua (1287 m asl) its highest peak, belongs to the internal Penninic Units of the Western Alps and is located at the boundary between Western Alps and Northern Apennines. It is separated from the Apennine chain by the Sestri Voltaggio zone to the east and bordered to the south by the Ligurian sea and to the north by the Tertiary sediments (continental to shallow marine breccias, conglomerates and sandstones) of the Tertiary Piedmont Basin [40-43] and it is in contact to the west with the Hercynian continental basement rocks of the Savona Massif [44]. The Voltri tectono-metamorphic unit corresponds to a remnant of the oceanic lithosphere of the Jurassic Piedmont-Ligurian ocean subducted during plate 
convergence between Europe and Adria [39,45-49]. It is composed of metamorphic ophiolitic rocks with associated metasediments and slices of lithospheric mantle placed at the top of the meta-ophiolite series (Figure 1b). Meta-ophiolites mainly consist of serpentinites, metagabbros, and metabasites; associated metasediments comprise calc-schists, and minor mica-schists and quartz-schists; mantle rocks include lherzolite and harzburgite and minor fractions of pyroxenite and dunite [39,43,45,46,50-54].

From lower Eocene until the Eocene-Oligocene boundary the Voltri Massif experienced a complex deformational evolution linked to different phases of the subduction-exhumation cycle of the Alpine orogenesis [44,55], with metamorphic conditions evolving from eclogitic to greenschist facies $[39,54,56,57]$.

The late orogenic evolution of the Ligurian Alps is coeval with the deposition of the Tertiary Piedmont Basin sedimentary succession [40,42]. Its sedimentation occurred in the Oligo-Miocene when three main tectonic episodes occurred: the exhumation of the Ligurian sector of the Western Alps, the opening of the Liguro-Provençal basin accompanied by the Corsica-Sardinia anticlockwise rotation [58,59], and the formation of the Apennines [42].

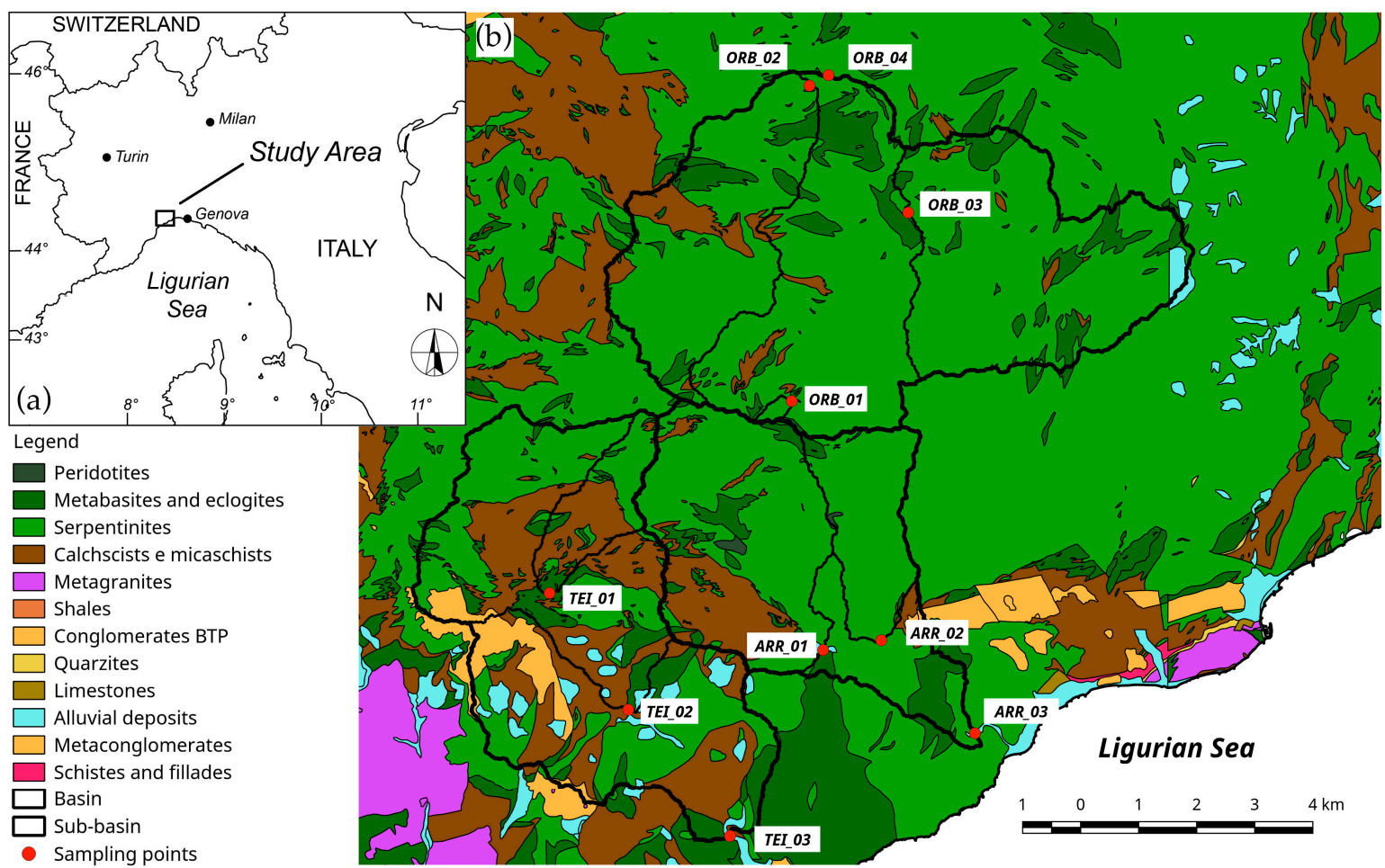

Figure 1. (a) Location of the study area; (b) geo-lihological map, simplified from the litholgical map of Regione Liguria [38].

The subsequent tectonic extensional regime (since early-middle Miocene) caused the development of a dense suite of normal faults that shaped the geomorphology of the study area, defining the current aspect of the coast and the hypsometry of this coastal section of Ligurian Alps.

The geomorphological and hydrological features of the Voltri Massif show some marked differences between the southern side, draining toward the Ligurian Sea, and the northern side, draining towards the Po plain. The southern side of the massif is characterized by steep slopes, streams with low sinuosity, and N-S elongated drainage basins; the northern side is characterized by gentle slopes and a more complex drainage network. The rapid uplift of the Thyrrenian margin is the reason why the basins draining toward the Ligurian Sea are steeper than those draining toward the Po Plain where the uplift is hampered by the load of the Tertiary Piedmont Basin sediments [60]. 
The study area is characterized by a long-period (30 years) averaged maximum temperature of $27^{\circ} \mathrm{C}$ in August and a minimum of $6{ }^{\circ} \mathrm{C}$ in January; the annual average rainfall is about $1250 \mathrm{~mm}$ with two precipitation maxima in October and April and a minimum in July [61].

\section{Materials and Methods}

\subsection{Theoretical Background}

Considering the paragenesis of the ultramafic rocks characterizing the study area [50,62], some of the most relevant weathering reactions that affect river water composition and soil formation are: dissolution of olivine (e.g., forsterite),

$$
\mathrm{Mg}_{2} \mathrm{SiO}_{4}+4 \mathrm{CO}_{2}+4 \mathrm{H}_{2} \mathrm{O} \rightarrow 2 \mathrm{Mg}^{2+}+4 \mathrm{HCO}_{3}^{-}+\mathrm{H}_{4} \mathrm{SiO}_{4}
$$

dissolution of pyroxene (e.g., enstatite),

$$
\mathrm{Mg}_{2} \mathrm{Si}_{2} \mathrm{O}_{6}+4 \mathrm{CO}_{2}+6 \mathrm{H}_{2} \mathrm{O} \rightarrow 2 \mathrm{Mg}^{2+}+4 \mathrm{HCO}_{3}^{-}+2 \mathrm{H}_{4} \mathrm{SiO}_{4},
$$

serpentine dissolution,

$$
\mathrm{Mg}_{3} \mathrm{Si}_{2} \mathrm{O}_{5}(\mathrm{OH})_{4}+6 \mathrm{CO}_{2}+5 \mathrm{H}_{2} \mathrm{O} \rightarrow 3 \mathrm{Mg}^{2+}+6 \mathrm{HCO}_{3}{ }^{-}+2 \mathrm{H}_{4} \mathrm{SiO}_{4},
$$

and alteration of anorthite to kaolinite,

$$
\mathrm{CaAl}_{2} \mathrm{Si}_{2} \mathrm{O}_{8}+2 \mathrm{CO}_{2}+3 \mathrm{H}_{2} \mathrm{O} \rightarrow \mathrm{Al}_{2} \mathrm{Si}_{2} \mathrm{O}_{5}(\mathrm{OH})_{4}+2 \mathrm{HCO}_{3}{ }^{-}+\mathrm{Ca}^{2+}
$$

In the study area some reactions involving the rocks of the metasedimentary cover (where present) may occur, such as the alteration of muscovite and feldspars to hydroxides and/or clay minerals (e.g., muscovite to kaolinite),

$$
2 \mathrm{KAl}_{2}\left(\mathrm{Si}_{3} \mathrm{Al}\right) \mathrm{O}_{10}(\mathrm{OH})_{2}+5 \mathrm{H}_{2} \mathrm{O}+2 \mathrm{CO}_{2} \rightarrow 3 \mathrm{Al}_{2} \mathrm{Si}_{2} \mathrm{O}_{5}(\mathrm{OH})_{4}+2 \mathrm{~K}^{+}+2 \mathrm{HCO}_{3}{ }^{-},
$$

and the congruent dissolution of calcite

$$
\mathrm{CaCO}_{3}+\mathrm{H}_{2} \mathrm{O}+\mathrm{CO}_{2} \rightarrow \mathrm{Ca}^{2+}+2 \mathrm{HCO}_{3}^{-} .
$$

Chemical weathering of silicates and carbonates consumes atmospheric/soil carbon dioxide, causes the increase of alkalinity and the increase of dissolved cations and silica in the solution. For each reaction, the moles of atmospheric/soil $\mathrm{CO}_{2}$ consumed by the weathering of one mole of mineral can be computed from the concentration of cations in solution, considering the stoichiometry of the reactions. For the Equations (1) to (4), the molal ratio between consumed $\mathrm{CO}_{2}$ and divalent cations in solution is 2. Similar reactions, showing the same molal ratio between cations in solution and consumed $\mathrm{CO}_{2}$, could be written for most of the silicates containing calcium, magnesium and ferrous iron. For the reactions involving silicates with monovalent cations (e.g., Equation (5)) and carbonates (e.g., Equation (6)) the molal ratio between consumed $\mathrm{CO}_{2}$ and cations in solution is 1.

On the long term $(>1 \mathrm{Ma})$, part of the atmospheric carbon consumed by weathering is returned to the atmosphere through several processes: (i) the $\mathrm{CO}_{2}$ consumed by weathering of carbonates in the continents is completely returned to the atmosphere through carbonate precipitation in the ocean (reverse of Equation (6)); (ii) half of the $\mathrm{CO}_{2}$ consumed during weathering of $\mathrm{Ca}$ and $\mathrm{Mg}$ silicates is precipitated as $\mathrm{CaCO}_{3}$ and half is released back into the atmosphere as $\mathrm{CO}_{2}$; (ii) $\mathrm{Na}^{+}$and $\mathrm{K}^{+}$ ions, transported by rivers to the ocean, may undergo reverse weathering to form authigenic clays and $\mathrm{CO}_{2}$ [63]. As a result, while on the short term both carbonate and silicate weathering consume 
atmospheric $\mathrm{CO}_{2}$, on the long term only weathering of $\mathrm{Ca}$ and $\mathrm{Mg}$ silicate minerals is a net sink for atmospheric/soil $\mathrm{CO}_{2}[8,23,62]$.

Considering the stoichiometric coefficients of Equations (1) to (6), it is possible to compute two different mass balance equations relating atmospheric/soil $\mathrm{CO}_{2}$ consumption to the composition of river waters. The first equation is related to short term carbon cycle and the second is for the long term:

$$
\begin{gathered}
F \mathrm{CO}_{2} \text {-short }=F \mathrm{Na}_{\text {sil }}+F \mathrm{~K}_{\text {sil }}+2 \mathrm{FMg}_{\text {sil }}+F \mathrm{Mg}_{\text {carb }}+2 \mathrm{FCa}_{\text {sil }}+F \mathrm{Ca}_{\text {carb }}+2 F \mathrm{Fe}_{\text {sil }}, \\
F \mathrm{CO}_{2} \text {-long }=F \mathrm{Mg}_{\text {sil }}+F \mathrm{Ca}_{\text {sil }}+F \mathrm{Fe}_{\text {sil }},
\end{gathered}
$$

where $\mathrm{FCO}_{2}$-short and $\mathrm{FCO}_{2}$-long are the fluxes of atmospheric carbon dioxide consumed by weathering in the short and long term, $F X$ is the flux of a generic cation $\mathrm{X}$, given by its molal concentration multiplied by the runoff, and the suffixes sil and carb stand for silicate and carbonate, indicating the origin of the dissolved chemical species.

The application of the mass balances (7) and (8) are based on the assumption that carbonic acid is the only source of protons in the weathering reactions and that the contribution related to sulphide minerals oxidation is negligible. In addition, it is important to note that dissolved iron in surface water is often fixed at very low concentrations by oxides/hydroxides precipitation and therefore the measured concentrations could be an underestimation of the total amount of Fe deriving from silicate weathering.

\subsection{Phases of the Study}

In this work the relationships among dissolved loads, natural weathering rates and $\mathrm{CO}_{2}$ consumed by weathering reactions are investigated in three streams whose drainage basins are mainly composed by the ophiolites of the Voltri Massif (Figure 2). Two streams (Teiro and Arrestra) run southward towards the Ligurian Sea and the third one (Orba) runs northwards up to its confluence with the Bormida river, a right tributary of the Po river.

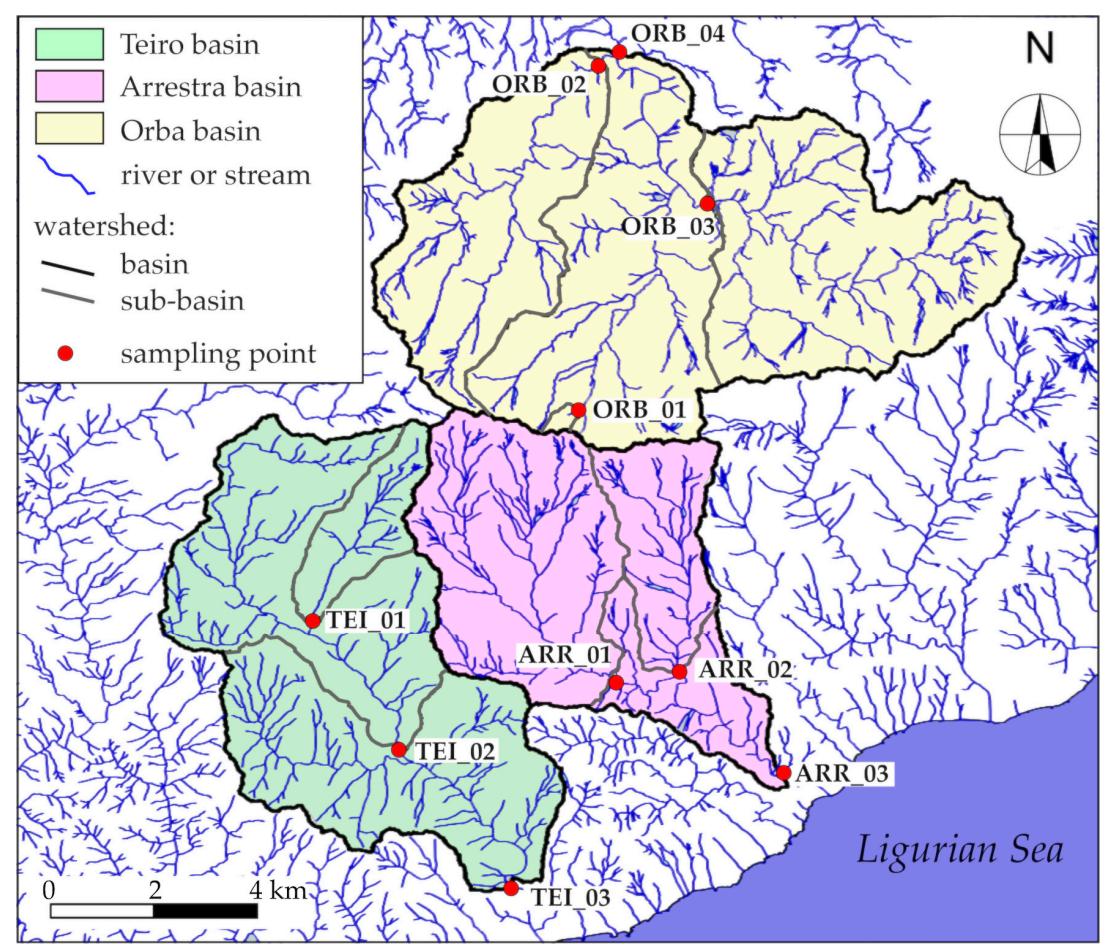

Figure 2. Drainage basins and location of the sampling points. 
The study has been carried out in three steps: (i) definition of the hydrologic, geographic, and geologic features of the studied basins and subdivision of the main drainage basins in smaller sub-basins using a GIS based approach, (ii) stream sampling, chemical and isotopic analyses (iii) geochemical mass balance and estimation of natural weathering rates and $\mathrm{CO}_{2}$ consumption rates based on the Equations (7) and (8).

\subsection{Definition of the Drainage Basins}

Teiro and Arrestra streams are characterized by NW-SE elongated catchments with very steep morphologies, on the contrary the drainage basin of the Orba stream, draining on the opposite side of the watershed, is characterized by a relatively gentle morphology after a steep descent just behind the main divide. The elevation of the studied areas ranges from a few meters above sea level up to the 1287 $\mathrm{m}$ above sea level (a.s.l.) of Monte Beigua. The three drainage basins and other derived parameters (Figure 2) were defined from the $5 \mathrm{~m}$ spatial resolution Digital Terrain Model of the Regione Liguria [63]. Each drainage basin was further subdivided in different sub-basins: Teiro basin was subdivided in three sub-basins following a nested pattern, where each sub-basin is completely contained in the downstream sub-basin; Arrestra basin and Orba basin were subdivided in three and four sub-basins respectively, following an additive pattern, where each sub-basin, except for the lowest one, is not spatially connected to the others, eventually sharing just a divide with the adjacent sub-basins. To be more precise while Teiro 3 contains Teiro 2, that contains Teiro 1 (nested patterns), Arrestra 3 contains both Arrestra 2 and Arrestra 1, but Arrestra 2 does not contain Arrestra 1 (additive pattern). In any case, the outlet of the lowest sub-basin (Teiro 3, Arrestra 3, and Orba 4) drains the totality of the basin area.

For each basin and sub-basin, the morphological parameters as surface area, average elevation and statistics were computed using GRASS GIS 7.6 packages [64]. The main features of the three basins are reported in Table 1.

Table 1. Surface area and average elevation of drainage sub-basins.

\begin{tabular}{cccccc}
\hline $\begin{array}{c}\text { Drainage } \\
\text { Basin }\end{array}$ & Sub-Basin $\mathbf{1}$ & Surface $\left.\mathbf{( k m}^{\mathbf{2}}\right)$ & $\begin{array}{c}\text { Mean } \\
\text { Elevation } \\
(\mathbf{m} \text { a.s.l) }\end{array}$ & $\begin{array}{c}\text { Minimum } \\
\text { Elevation } \\
(\mathbf{m} \text { a.s.l) }\end{array}$ & $\begin{array}{c}\text { Maximum } \\
\text { Elevation } \\
\mathbf{( m} \text { a.s.l) }\end{array}$ \\
\hline Teiro & Teiro 1 & 2.9 & 843 & 370 & 1287 \\
Teiro & Teiro 2 & 14.6 & 665 & 100 & 1287 \\
Teiro & Teiro 3 & 26.5 & 487 & 10 & 1287 \\
Arrestra & Arrestra 1 & 11.7 & 741 & 171 & 1287 \\
Arrestra & Arrestra 2 & 4.7 & 677 & 139 & 1145 \\
Arrestra & Arrestra 3 & 20.0 & 632 & 20 & 1287 \\
Orba & Orba 1 & 0.2 & 1137 & 1081 & 1198 \\
Orba & Orba 2 & 10.7 & 939 & 730 & 1287 \\
Orba & Orba 3 & 14.6 & 915 & 610 & 1181 \\
Orba & Orba 4 & 39.6 & 919 & 540 & 1287 \\
\hline
\end{tabular}

${ }^{1}$ The hierarchy of sub-basins is graphically shown in Figure 2.

The relative abundances of outcropping rocks in the three drainage basins were computed with GRASS, extracting the data from the simplified geo-lithological map (Figure 1) derived from a multi-source geological map of Regione Liguria [38]; the results (Table 2) show that the Arrestra and the Orba basins are characterized by the prevalence of serpentinites, metagabbros, and eclogites while the Teiro basin shows a greater heterogeneity with a relevant fraction of metasedimentary rocks (mainly calc-schists) alternating with ultramafic meta-ophiolites. Post-orogenic sedimentary deposits (conglomerates) are negligible and in any case the constituent material is principally made by bedrock lithotypes. 
Table 2. Relative abundance (surface area \%) of the rock types outcropping in the ten sub-basins considered in this work, grouped starting from the map of Figure $1 \mathrm{~b}$.

\begin{tabular}{cccccc}
\hline Sub-Basin & Peridotites & Metabasites & Serpentinite & Calc-Schistes & Conglomerates \\
\hline Teiro 1 & 0.0 & 10.3 & 41.4 & 48.3 & 0.0 \\
Teiro 2 & 0.0 & 12.4 & 47.6 & 36.6 & 3.4 \\
Teiro 3 & 0.0 & 14.0 & 43.4 & 36.2 & 6.4 \\
Arrestra 1 & 0.9 & 10.3 & 63.9 & 24.8 & 0.0 \\
Arrestra 2 & 0.0 & 4.3 & 93.6 & 2.1 & 0.0 \\
Arrestra 3 & 0.5 & 12.5 & 71.8 & 14.9 & 0.0 \\
Orba 1 & 0.0 & 0.0 & 100.0 & 0.0 & 0.0 \\
Orba 2 & 0.0 & 12.1 & 78.5 & 9.3 & 0.0 \\
Orba 3 & 0.0 & 13.7 & 84.2 & 2.1 & 0.0 \\
Orba 4 & 0.0 & 13.4 & 81.6 & 5.1 & 0.0 \\
\hline
\end{tabular}

* Metabasites includes metagabbros, eclogites, and amphibolites.

\subsection{Sampling and Analyses}

Ten sampling sites were selected for this study, located near the sub-basin outlets (three in the Arrestra basin, three in the Teiro basin, and four in the Orba basin) (Figure 2). Sampling was performed twice, during the dry (July 2016) and wet (April 2017) seasons, for a total of twenty samples. Also measured on each sampling site was the stream discharge $(\mathrm{Q})$ using the velocity-area method.

For each sample, temperature, electrical conductivity, $\mathrm{pH}$, Eh, and dissolved oxygen (DO) were measured in the field with a laboratory pre-calibrated HANNA HI 9829 multiparameter meter (electrical conductivity: resolution $=1 \mu \mathrm{S} / \mathrm{cm}$, accuracy $= \pm 1 \%$; $\mathrm{pH}$ : resolution $=0.01$, accuracy $= \pm 0.02 \mathrm{pH}$; Eh: resolution $=0.1 \mathrm{mV}$, accuracy $= \pm 0.5 \mathrm{mV}$; DO: resolution $=0.01 \mathrm{mg} / \mathrm{L}$, accuracy $= \pm 1 \%$ ). Total and carbonate alkalinity were determined in the field on a fresh water sample with digital titrator HACH 16900 by acid titration with $\mathrm{H}_{2} \mathrm{SO}_{4} 0.16 \mathrm{~N}$ on $25 \mathrm{~mL}$ of water using Phenolphthalein and Bromochresol Green-Methyl Red as indicators.

Water samples for chemical analyses were filtered with $0.45 \mu \mathrm{m}$ filters and collected in three $50 \mathrm{~mL}$ polyethylene bottles. One aliquot was immediately acidified with $0.5 \mathrm{~mL}$ of concentrated suprapure $\mathrm{HCl}$ in order to stabilize the sample, preventing algal growth and carbonate precipitation. A second aliquot was acidified with $0.5 \mathrm{~mL}$ of ultrapure $\mathrm{HNO}_{3}$ to avoid precipitation of metals as metal oxides or hydroxides. A further sample for the determination of the isotopic composition of water $\left(\delta \mathrm{D}, \delta^{18} \mathrm{O}\right)$ was collected in a $100 \mathrm{~mL}$ polyethylene bottle preventing the formation of head space. Finally, for the determination of $\delta^{13} \mathrm{C}$ of total dissolved inorganic carbon $\left(\delta^{13} \mathrm{C}_{\mathrm{TDIC}}, \mathrm{TDIC}\right)$, all the dissolved carbon species were precipitated in the field as $\mathrm{SrCO}_{3}$ by adding an excess of $\mathrm{SrCl}_{2}$ and $\mathrm{NaOH}$ to $1000 \mathrm{~mL}$ of water. In the laboratory carbonate precipitates were filtered, washed with distilled water, and dried in a CO2-free atmosphere.

All the chemical determinations were performed at the Geochemical Laboratory of the Perugia University. Sulphate, $\mathrm{NO}_{3}{ }^{-}, \mathrm{Cl}^{-}$, and $\mathrm{F}^{-}$were determined by ion-chromatography (Dionex DX120 with AS50 autosampler). Ca and $\mathrm{Mg}$ concentrations were determined by atomic absorption flame spectrometry (IL951 AA/AE), using the $\mathrm{HCl}$ acidified sample for the determination of $\mathrm{Ca}$, while $\mathrm{Na}$ and $\mathrm{K}$ were determined by atomic emission flame spectrometry (IL951 AA/AE). Low range protocol analyses for $\mathrm{Al}$ and silica were determined by UV/Vis spectrophotometry (HACH DR2010), using Eriochrome Cyanine R and silicomolybdate methods respectively. The detection limits are: $0.01 \mathrm{mg} / \mathrm{L}$ for $\mathrm{Ca}, \mathrm{Mg}, \mathrm{Na}, \mathrm{K}, \mathrm{F}^{-}$, and $\mathrm{NO}_{3}{ }^{-}, 0.03 \mathrm{mg} / \mathrm{L}$ for $\mathrm{Cl}^{-}$and $\mathrm{SO}_{4}{ }^{2-}, 4 \mu \mathrm{g} / \mathrm{L}$ for $\mathrm{Al}, 5 \mu \mathrm{g} / \mathrm{L}$ for total iron, and $0.45 \mathrm{mg} / \mathrm{L}$ for $\mathrm{SiO}_{2}$.

All the laboratory analytical methods and the field alkalinity determinations have an accuracy better than $2 \%$. The total analytical error, evaluated checking the charge balance, is about $0.8 \%$ on average, and is lower than $3 \%$ for all the samples. 
The analyses of the hydrogen and oxygen stable isotope ratios were performed at the isotope laboratory of Parma University using a Thermo Delta Plus mass spectrometer and the isotope analyses of TDIC were performed by means of standard mass spectrometry techniques using a Delta $S$ mass spectrometer at CNR-IGG, Section of Florence. The values of $\delta \mathrm{D}$ and $\delta^{18} \mathrm{O}$ are referred as $\delta(\%)$ of the standard SMOW. The values of $\delta^{13} \mathrm{C}$ are referred as $\delta(\%)$ of the standard PDB. Analytical errors are: $\pm 1 \%$ o for $\delta \mathrm{D}, \pm 0.1 \%$ o for $\delta^{18} \mathrm{O}$, and $\delta^{13} \mathrm{C}$.

The location of the sampling points is shown in Figure 2, field data are in Table S1 and the results of isotopic and chemical analyses are listed in Table S2.

\subsection{Computation of Runoff, Solute Flux, Weathering Rates, and $\mathrm{CO}_{2}$ Consumption Rates}

For each drainage basin and sub-basin, we computed (i) the runoff, given by the ratio between streamflow (Q) and surface area, (ii) the flux of dissolved solids, given by the product of total dissolved solids (TDS) by runoff, (iii) the weathering rate, calculated from the difference between TDS and the atmospheric/biologic components multiplied by runoff, and (iv) $\mathrm{FCO}_{2}$-short and $\mathrm{FCO}_{2}$-long, from Equations (7) and (8).

For the estimation of the weathering rates and $\mathrm{CO}_{2}$ consumption rates it was first necessary to subtract the rain/atmospheric contribution to the stream waters composition [23,65]. Assuming that chloride in stream waters derive entirely from the rain/atmospheric input, the concentration of each ion $(\mathrm{X})$ has been corrected using the ion to chloride molal ratios in rainwater,

$$
\mathrm{X}_{\text {corr }}=\mathrm{X}_{\text {stream }}-\mathrm{Cl}_{\text {stream }} *(\mathrm{X} / \mathrm{Cl})_{\text {rain }}
$$

where $\mathrm{X}_{\text {corr }}$ is the ion concentration after the correction for the rain/atmospheric contribution and the suffixes stream and rain stand for stream water and rainwater. Calculations were performed considering the average the $\mathrm{X} / \mathrm{Cl}$ molal ratios in rainwaters of the northern Mediterranean area and Ligurian sea $[66,67]$.

For some sub-basins (see next section) it was also necessary to discriminate the fraction of Ca deriving from silicate weathering from the fraction deriving from calcite dissolution $\left(\mathrm{Ca}_{\text {sil }}\right.$ and $\mathrm{Ca}_{\text {carb }}$ in Equations (7) and (8)). The $\mathrm{Ca} / \mathrm{Mg}$ molal ratio (0.59) of the waters sampled in the Orba basin and Arrestra 2 sub-basin, where the amount of calcite is negligible (Table 2), has been considered to be representative of the interaction of stream water with ultramafic rocks. The amount of Ca deriving from calcite dissolution was then computed for each sample from:

$$
\mathrm{Ca}_{\text {carb }}=\mathrm{Ca}-0.59 \mathrm{Mg}_{\text {sil }} \text {. }
$$

\section{Results}

\subsection{Chemical and Isotopic Composition of Stream Waters}

The stream waters of the study area, during the July 2016 campaign, were characterized by temperatures between 19.1 and $28.6^{\circ} \mathrm{C}, \mathrm{pH}$ from 5.79 to 8.98 with a mean value of 8.03, electrical conductivity (EC) from 80 to $315 \mu \mathrm{S}$ with a mean value of $177 \mu \mathrm{S} / \mathrm{cm}$, average dissolved oxygen (DO) of $7.24 \pm 0.83 \mathrm{mg} / \mathrm{L}$, and an average Eh of $210 \pm 22 \mathrm{mV}$. The same streams, during the April 2017 campaign, were characterized by temperatures between 7.8 and $13.8^{\circ} \mathrm{C}, \mathrm{pH}$ values from 7.54 to 9.17 $($ mean value $=8), \mathrm{EC}$ values from 70 to $250 \mu \mathrm{S} / \mathrm{cm}$ (mean value $=136 \mu \mathrm{S} / \mathrm{cm})$, average $\mathrm{DO}=10.11 \pm$ $1.18 \mathrm{mg} / \mathrm{L}$ and average $\mathrm{Eh}=236 \pm 25 \mathrm{mV}$.

The values of $\mathrm{pH}$ did not show any significant change between the two campaigns, while EC, total dissolved solids (TDS-computed from analyses), DO and Eh showed significant seasonal variations. EC decreased of almost 25\% from the July 2016 campaign (dry season) to the April 2017 campaign (wet season). Similarly, also TDS values were higher for the samples taken during the dry season (mean of July 2016 campaign TDS $=116 \pm 50 \mathrm{mg} / \mathrm{L}$; mean of April 2017 campaign TDS $=88 \pm 36 \mathrm{mg} / \mathrm{L}$ ). These variations of EC and TDS are likely caused by the dilution effect of rainwater during the wet season. 
Conversely, DO and Eh values increased from the dry to the wet season probably because oxygen solubility in water increases as temperature decreases (e.g., at 1 bar and $25^{\circ} \mathrm{C}$, air-saturated water would hold $7.7 \mathrm{mg} / \mathrm{L}$ of dissolved oxygen, while at 1 bar and $5{ }^{\circ} \mathrm{C}$ there would be $9.7 \mathrm{mg} / \mathrm{L}$ of dissolved oxygen at $100 \%$ air saturation).

In the diagram $\delta^{18} \mathrm{O}$ vs. $\delta \mathrm{D}$ (Figure 3) the stream waters of the study area plot between the global meteoric water line (GMWL [68]) and the meteoric water line of the Mediterranean area (MMWL [69]), indicating that the precipitations in the Voltri Massif derive both from weather fronts originating north of the European continent, in the Atlantic Ocean, and weather fronts coming from the Mediterranean Sea. Furthermore, stream waters plot close to the groundwaters of the Voltri Massif [70] and do not show any evident isotopic shift due to evaporation.

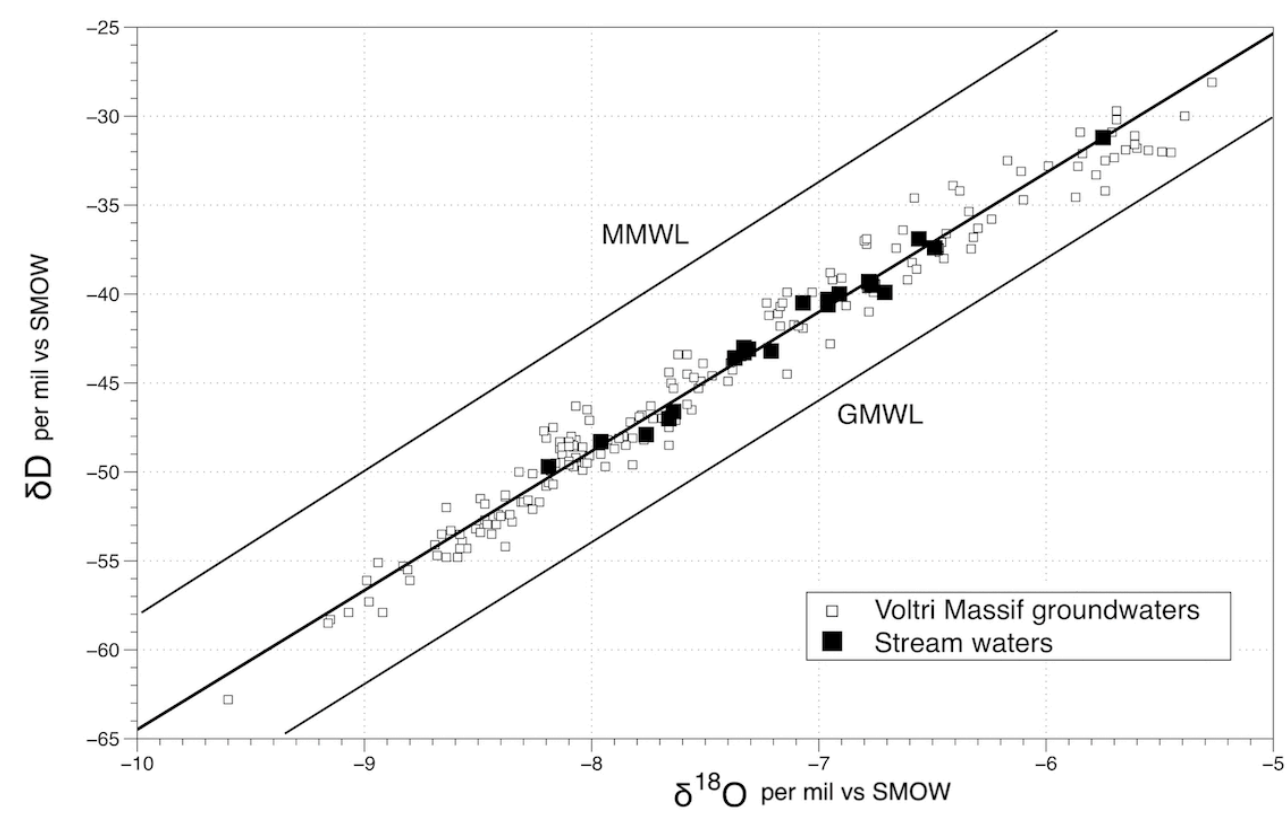

Figure 3. $\delta \mathrm{D}$ vs. $\delta^{18} \mathrm{O}$ diagram. The stream waters are compared to the global meteoric water line $(\delta \mathrm{D}$ $=8 \delta^{18} \mathrm{O}+10$ [68]) and to the Mediterranean meteoric water line $\left(\delta \mathrm{D}=8 \delta^{18} \mathrm{O}+22\right.$ [69]). In the same diagram are reported also the groundwaters of the Voltri Massif [70].

The Langelier-Ludwig diagram (Figure 4a) shows that all the samples are characterized by a bicarbonate-earth alkaline composition similar to the composition of groundwaters of the Voltri Massif [67]. The salinity ( $46<$ TDS $<205 \mathrm{mg} / \mathrm{L}$ ) is lower, on average, than the rivers of the Alpine region $(96<\mathrm{TDS}<551 \mathrm{mg} / \mathrm{L}$ [23]). Consistently with the composition of the outcropping rocks, the $\mathrm{Mg}$ concentration is relatively high and the $\mathrm{Mg} / \mathrm{Ca}$ molal ratio varies from 0.18 to 1.56 suggesting that dissolution of serpentine and other mafic minerals is the main water-gas-rock interaction process occurring in the studied waters.

In the trilinear $\mathrm{Mg}-\mathrm{SiO}_{2}-\mathrm{HCO}_{3}$ plot of Figure $4 \mathrm{~b}$, the samples are compared to the theoretical composition of solutions deriving from the dissolution of serpentine, olivine and pyroxene according to Equations (1) to (3). For the dissolution of pure Mg-silicates (e.g., serpentine, enstatite, forsterite) the theoretical solutions plots along the line $\mathrm{HCO}_{3} / \mathrm{Mg}=2$, for silicates containing other divalent cations in addition to $\mathrm{Mg}$, the solutions are characterized by an higher $\mathrm{HCO}_{3} / \mathrm{Mg}$ molal ratio (for example the solution obtained from dissolution of the $\mathrm{Fo}_{50}-\mathrm{Fa}_{50}$ term of the olivine series is characterized by $\mathrm{HCO}_{3} / \mathrm{Mg}=4$ ). About $45 \%$ of the samples fall between the $\mathrm{HCO}_{3} / \mathrm{Mg}=2$ and $\mathrm{HCO}_{3} / \mathrm{Mg}=4$ lines and below the curve characterized by a $\mathrm{HCO}_{3} / \mathrm{SiO}_{2}=4$, representing olivine dissolution. The composition of these waters if fully explained by dissolution of serpentine and/or other Mg-bearing silicates. About $55 \%$ of the data show a $\mathrm{HCO}_{3} / \mathrm{SiO}_{2}$ higher than the olivine dissolution ratio. In order to explain the composition of these samples is necessary to consider some additional processes together with the 
dissolution of Mg-silicates. Plausible processes are the alteration of aluminosilicates and the congruent dissolution of carbonates.
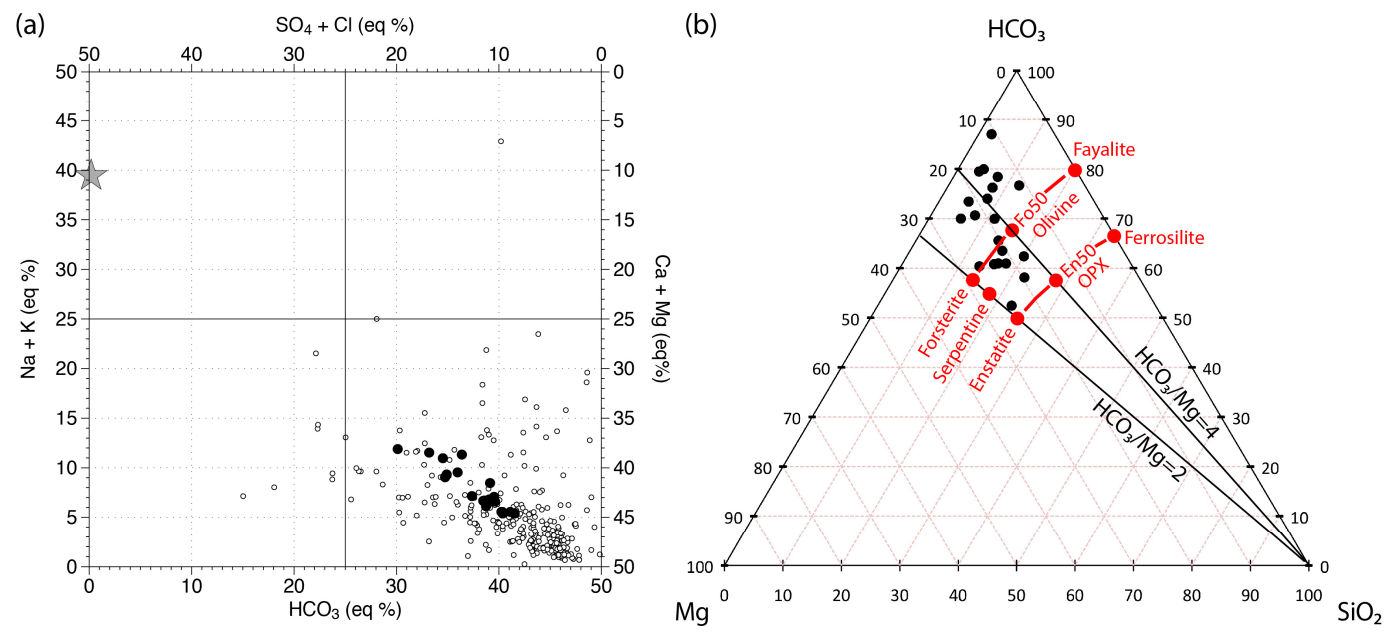

Figure 4. (a) Langelier-Ludwig diagram showing the sampled stream waters (black dots) and 375 groundwaters of the Voltri Massif (white dots [70]). For reference, mean seawater composition is plotted as a grey star. (b) Trilinear $\mathrm{Mg}-\mathrm{SiO}_{2}-\mathrm{HCO}_{3}$ plot based on molal composition: the composition of stream waters (black dots) are compared to composition of theoretical solutions deriving from dissolution of some relevant mafic minerals (red dots). The red lines represent the olivine and orthopyroxene series. The $\mathrm{HCO}_{3} / \mathrm{Mg}=2$ line represents the solutions resulting from dissolution of pure $\mathrm{Mg}$ silicates while the $\mathrm{HCO}_{3} / \mathrm{Mg}=4$ line represents the solutions deriving from dissolution of silicates where $\mathrm{Mg}$ is $50 \%$ of the divalent cations.

In order to assess the sources and processes controlling stream chemistry, aqueous speciation and saturation index (SI) calculations have been performed with the PHREEQC geochemical code [71] using the "llnl" database [72]. All the samples are strongly undersaturated with respect to the minerals of the serpentine, olivine and pyroxene groups (saturation indexes ranging from -5 to -70 ) indicating that their dissolution is an irreversible process. Saturation indexes of secondary minerals and carbon dioxide partial pressure (Table 3) show that:

- $\quad$ all the samples are saturated or supersaturated with respect to amorphous $\mathrm{Fe}(\mathrm{OH})_{3}$ and goethite, suggesting that Fe oxyhydroxides control the iron concentration in solution;

the samples of the Arrestra and Orba streams are supersaturated with respect to illite, kaolinite, and clay minerals of the smectite group (e.g., montmorillonite), close to equilibrium or supersaturated with respect to gibbsite and quartz (but undersaturated with respect to amorphous silica) and undersaturated with respect to calcite, dolomite, magnesite and brucite;

- $\quad$ the samples of the Teiro stream show extremely variable saturation conditions for clay minerals and quartz, are generally undersaturated with respect to gibbsite, brucite, and magnesite (except for Teiro 3 samples), close to equilibrium or supersaturated with respect to calcite (in particular during the July 2016 survey) and supersaturated with respect to ordered dolomite;

- the logarithm of carbon dioxide partial pressure $\left(\log _{10} \mathrm{pCO}_{2}\right)$ vary within a relatively small interval, from -4.27 to -2.88 , following a log-normal distribution (Figure 5). Its probability distribution is characterized by a mean of $-3.37\left(10^{-3.37} \mathrm{bar}\right)$ and a median of $-3.30\left(10^{-3.30} \mathrm{bar}\right)$, very close to the value of equilibrium with the atmospheric carbon dioxide $\left(10^{-3.39}\right.$ bar assuming a $\mathrm{CO}_{2}$ concentration in atmosphere of $405 \mathrm{ppm}$ ), and suggests that most of the dissolved inorganic carbon derive from the atmosphere. This hypothesis is supported also by the isotopic composition of TDIC $\left(-14.27 \leq \delta^{13} \mathrm{C}_{\text {TDIC }} \leq-6.59\right)$ that is consistent with an atmospheric origin $\left(\delta^{13} \mathrm{C}_{\mathrm{atm}} \approx-8\right)$ of dissolved carbon with a minor contribution of soil $\mathrm{CO}_{2}$ deriving from organic matter oxidation $\left(\delta^{13} \mathrm{C}_{\text {org }} \approx-28\right)$. 
Table 3. $\log _{10}$ of the partial pressure of $\mathrm{CO}_{2}$ and saturation indexes.

\begin{tabular}{|c|c|c|c|c|c|c|c|c|c|c|c|c|c|c|}
\hline ID & $\begin{array}{l}\log _{10} \\
\mathrm{pCO}_{2}\end{array}$ & Caclite. & $\begin{array}{l}\text { Dol. } \\
\text { ord. }\end{array}$ & $\begin{array}{l}\text { Dol. } \\
\text { dis. }\end{array}$ & Magn. & Brucite & Gibbsite & $\mathrm{Qz}$ & $\begin{array}{c}\mathrm{SiO}_{2} \\
\text { am. }\end{array}$ & Montm. & Kaol. & Illite & Goeth. & $\mathrm{Fe}(\mathrm{OH})_{3}$ \\
\hline \multicolumn{15}{|c|}{ July 2016} \\
\hline Arr. 1 & -2.88 & -0.34 & 0.36 & -1.39 & -0.94 & -4.35 & 0.27 & 0.25 & -1.05 & 1.94 & 1.74 & 1.09 & nc & nc \\
\hline Arr. 2 & -3.14 & -0.96 & -0.44 & -2.02 & -1.14 & -4.37 & 0.00 & 0.47 & -0.84 & 2.35 & 1.63 & 1.06 & $\mathrm{nc}$ & $\mathrm{nc}$ \\
\hline Arr. 3 & -3.18 & -0.21 & 0.88 & -0.67 & -0.55 & -3.60 & 0.22 & 0.52 & -0.77 & 3.30 & 2.18 & 2.30 & 6.43 & 0.58 \\
\hline Teiro 1 & -3.43 & 0.06 & 0.77 & -0.83 & -0.97 & -4.05 & -0.29 & -0.32 & -1.66 & -1.14 & -0.55 & -1.90 & nc & $\mathrm{nc}$ \\
\hline Teiro 2 & -3.40 & 0.34 & 1.52 & -0.03 & -0.46 & -3.30 & $\mathrm{nc}$ & 0.22 & -1.08 & $\mathrm{nc}$ & Nc & nc & nc & $\mathrm{nc}$ \\
\hline Teiro 3 & -3.92 & 1.10 & 3.39 & 1.67 & 0.48 & -1.69 & -0.98 & 0.20 & -1.05 & 1.04 & -0.82 & -0.33 & 6.34 & 0.38 \\
\hline Orba 1 & -3.26 & -1.89 & -2.60 & -4.22 & -2.41 & -5.83 & nc & 0.37 & -1.00 & $\mathrm{nc}$ & Nc & nc & 6.96 & 1.48 \\
\hline Orba 2 & -3.23 & -1.23 & -1.10 & -2.70 & -1.55 & -4.84 & 0.51 & 0.48 & -0.87 & 2.96 & 2.62 & 1.97 & 6.58 & 0.95 \\
\hline Orba 3 & -3.31 & -1.60 & -1.65 & -3.26 & -1.73 & -4.95 & 0.25 & 0.25 & -1.10 & 1.55 & 1.64 & 0.73 & nc & nc \\
\hline Orba 4 & -3.11 & -1.23 & -1.13 & -2.72 & -1.57 & -4.91 & 0.21 & 0.41 & -0.92 & 2.18 & 1.91 & 1.13 & 6.54 & 0.87 \\
\hline \multicolumn{15}{|c|}{ April 2017} \\
\hline Arr. 1 & -3.29 & -0.80 & -0.57 & -2.21 & -1.48 & -5.01 & 0.36 & 0.48 & -0.92 & 2.60 & 2.27 & 1.59 & nc & $\mathrm{nc}$ \\
\hline Arr. 2 & -3.31 & -1.08 & -0.78 & -2.42 & -1.41 & -4.90 & 0.35 & 0.64 & -0.75 & 3.31 & 2.59 & 1.98 & 6.70 & 1.29 \\
\hline Arr. 3 & -2.98 & -1.09 & -0.99 & -2.64 & -1.62 & -5.43 & 0.60 & 0.33 & -1.07 & 2.18 & 2.44 & 1.43 & 6.69 & 1.27 \\
\hline Teiro 1 & -3.62 & -0.27 & 0.11 & -1.54 & -1.34 & -4.60 & 0.56 & 0.53 & -0.88 & 3.33 & 2.76 & 2.70 & nc & nc \\
\hline Teiro 2 & -3.84 & -0.17 & 0.51 & -1.13 & -1.03 & -4.00 & -0.18 & -0.06 & -1.45 & 0.05 & 0.12 & -0.77 & nc & nc \\
\hline Teiro 3 & -4.27 & 0.94 & 2.75 & 1.13 & 0.11 & -2.33 & -0.95 & 0.17 & -1.21 & 0.53 & -0.94 & -0.82 & nc & nc \\
\hline Orba 1 & -3.39 & -1.68 & -2.69 & -4.37 & -2.75 & -6.33 & 0.80 & -1.57 & -0.14 & 0.17 & 1.88 & 0.00 & nc & nc \\
\hline Orba 2 & -3.17 & -1.85 & -2.48 & -4.14 & -2.36 & -6.10 & 1.12 & 0.63 & -0.78 & 3.95 & 4.09 & 3.04 & 7.06 & 1.74 \\
\hline Orba 3 & -3.23 & -1.80 & -2.33 & -3.99 & -2.25 & -5.91 & 1.44 & -0.20 & -1.61 & 1.25 & 3.07 & 1.20 & $\mathrm{nc}$ & nc \\
\hline Orba 4 & -3.39 & -2.29 & -3.06 & -4.72 & -2.50 & -6.02 & 1.08 & 0.51 & -0.90 & 3.43 & 3.76 & 2.89 & 6.76 & 1.43 \\
\hline
\end{tabular}

$\mathrm{nc}=$ not computable. 


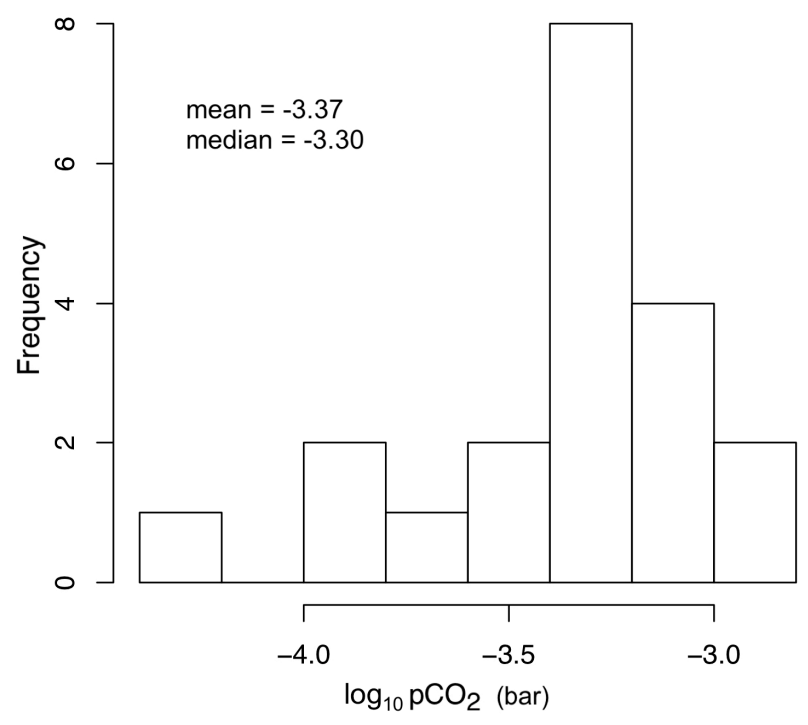

Figure 5. Histogram of $\log _{10} \mathrm{pCO}_{2}$.

In the study area the stream waters interact with ultramafic rocks and ultramafic soils, whose mineralogical composition is mostly inherited from the parent rock (serpentine, olivine, pyroxene) with minor authigenic species (clay minerals, $\mathrm{Fe}$ and $\mathrm{Al}$ oxyhydroxides) and a low organic matter content [73]. Irreversible, congruent dissolution of $\mathrm{Mg}$-silicates, under $\mathrm{pCO}_{2}$ conditions close to the atmospheric value, is the major process producing the observed chemical compositions of stream waters. However, considering that for Mg-silicates' dissolution the maximum possible value of the $\mathrm{HCO}_{3} / \mathrm{SiO}_{2}$ molal ratio in solution is 4 (corresponding to the congruent dissolution of olivine), in order to explain the composition of the samples with $\mathrm{HCO}_{3} / \mathrm{SiO}_{2}>4$ it is necessary to hypothesize the occurrence of an additional process such as incongruent dissolution of aluminosilicates, where the precipitation of clay minerals causes the relative increase of the $\mathrm{HCO}_{3} / \mathrm{SiO}_{2}$ ratio in solution. Furthermore, for the samples of the Teiro stream, characterized by very high $\mathrm{HCO}_{3} / \mathrm{Mg}$ ratios and equilibrium with calcite, also the dissolution of calcium carbonate has to be considered.

The samples of the Teiro stream are also strongly oversaturated with respect to ordered dolomite [74,75], but, despite this, the concentration of $\mathrm{Mg}$ in solution is not limited by dolomite precipitation. In fact, at low temperature and low salinity, primary precipitation of dolomite is extremely slow even at high supersaturations and is practically inhibited by reaction kinetics [76].

A further process to be discussed is the possible interaction of stream waters with brucite. Brucite is a common mineral in serpentinized peridotite and recent works demonstrate that often it is the fastest dissolving mineral, and might dominate other processes [77,78]. Brucite dissolution also increases the water saturation state with respect to hydrated $\mathrm{Mg}$ carbonate minerals [78] and both dissolution and precipitation of brucite might affect the computation of the $\mathrm{CO}_{2}$ consumption flux. However, only very minor amounts of brucite are present in the Voltri serpentinites and their influence on the composition of river waters is negligible. This depends on the tectonic-metamorphic evolution of the ultramafic rocks of the Voltri Massif: during the ocean stage of their evolution, the seafloor hydration led to widespread serpentinization of peridotites with formation of chrysotile and lizardite in association with magnetite and locally brucite [51,79]; subsequently, during the subduction-exhumation cycle of the Alpine orogenesis [44,55], ultramafic rocks experienced a high-pressure event during which brucite was consumed with the formation of metamorphic olivine in equilibrium with antigorite, diopside, Ti-clinohumite, and fluids [79]. As a result, only very minor amounts of brucite are present in the Voltri serpentinites. Furthermore, also in the recent carbonate deposits associated with the ultra-alkaline springs of the area, brucite is not present, as well as hydromagnesite and other hydrated $\mathrm{Mg}$ carbonates [80]. The chemical composition of river waters are consistent with these observations: (1) brucite saturation index are always very negative (Table 3) excluding the possibility of brucite 
precipitation; (2) stream waters are characterized by the $\mathrm{Mg} / \mathrm{SiO}_{2}$ ratios of $\mathrm{Mg}$-silicates or lower (Figure 4) suggesting that brucite dissolution does not affect significantly the composition of stream waters; in fact, if there were brucite dissolution, stream waters would have $\mathrm{Mg} / \mathrm{SiO}_{2}$ ratios higher than those of Mg-silicates dissolution and the samples would shift towards the lower left corner $(\mathrm{Mg})$ in the trilinear diagram of Figure 4.

\subsection{Runoff, Solute Fluxes, Weathering Rates, and $\mathrm{CO}_{2}$ Fluxes}

The results of the mass-balance calculations are summarized in Table 4.

Table 4. Runoff, solute flux, chemical weathering rates and fluxes of atmospheric $\mathrm{CO}_{2}$ consumed by chemical weathering considering both the short and the long-term carbon cycles. $\mathrm{FCO}_{2}$ data are reported both in $\mathrm{mol} \mathrm{km} \mathrm{km}^{-2} \mathrm{y}^{-1}$ and $\mathrm{t} \mathrm{km}^{-2} \mathrm{y}^{-1}$.

\begin{tabular}{|c|c|c|c|c|c|c|c|}
\hline \multirow{2}{*}{$\begin{array}{c}\text { Basin/ } \\
\text { Sub-Basin }\end{array}$} & \multirow{2}{*}{$\begin{array}{c}\text { Runoff } \\
\mathrm{L} \mathrm{s}^{-1} \mathrm{~km}^{-2}\end{array}$} & \multirow{2}{*}{$\begin{array}{c}\begin{array}{c}\text { Solute } \\
\text { Flux }\end{array} \\
\mathrm{t} \mathbf{k m}^{-2} \mathrm{y}^{-1}\end{array}$} & \multirow{2}{*}{$\begin{array}{c}\begin{array}{c}\text { Weathering } \\
\text { Rate }\end{array} \\
\mathbf{t} \mathbf{k m}^{-2} \mathrm{y}^{-1}\end{array}$} & \multicolumn{2}{|c|}{$\mathrm{FCO}_{2}$-Short } & \multicolumn{2}{|c|}{$\mathrm{FCO}_{2}$-Long } \\
\hline & & & & $\mathrm{mol} \mathrm{km}{ }^{-2} \mathrm{y}^{-1}$ & $\mathrm{t} \mathrm{km}^{-2} \mathrm{y}^{-1}$ & 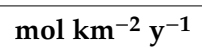 & $\mathrm{t} \mathrm{km}^{-2} \mathrm{y}^{-1}$ \\
\hline \multicolumn{8}{|c|}{ July 2016} \\
\hline \multicolumn{8}{|l|}{ Arrestra } \\
\hline Arrestra 1 & 1.7 & 8.1 & 2.9 & $5.96 \times 10^{5}$ & 2.6 & $2.25 \times 10^{4}$ & 1.0 \\
\hline Arrestra 2 & 21.3 & 66.0 & 19.5 & $5.44 \times 10^{5}$ & 24.0 & $2.72 \times 10^{5}$ & 12.0 \\
\hline Arrestra 3 & 8.3 & 79.9 & 30.3 & $5.84 \times 10^{5}$ & 25.7 & $2.30 \times 10^{5}$ & 10.1 \\
\hline $\begin{array}{c}\text { weighted } \\
\text { mean } \\
\text { Teiro }\end{array}$ & 7.5 & 34.6 & 11.8 & $2.68 \times 10^{5}$ & 11.8 & $1.19 \times 10^{5}$ & 5.2 \\
\hline Teiro 1 & 15.5 & 61.5 & 27.0 & $3.84 \times 10^{5}$ & 16.9 & $8.53 \times 10^{4}$ & 3.8 \\
\hline Teiro 2 & 2.1 & 15.1 & 5.5 & $9.56 \times 10^{4}$ & 4.2 & $3.55 \times 10^{4}$ & 1.6 \\
\hline Teiro 3 & 10.9 & 82.8 & 31.3 & $5.35 \times 10^{5}$ & 23.5 & $1.85 \times 10^{5}$ & 8.1 \\
\hline $\begin{array}{l}\text { weighted } \\
\text { mean } \\
\text { Orba }\end{array}$ & 7.5 & 48.6 & 18.9 & $3.24 \times 10^{5}$ & 14.3 & $1.08 \times 10^{5}$ & 4.8 \\
\hline Orba 1 & 15.0 & 23.7 & 8.5 & $1.51 \times 10^{5}$ & 6.6 & $6.02 \times 10^{4}$ & 2.6 \\
\hline Orba 2 & 7.0 & 17.2 & 5.4 & $1.28 \times 10^{5}$ & 5.6 & $6.10 \times 10^{4}$ & 2.7 \\
\hline Orba 3 & 6.8 & 13.7 & 3.9 & $1.15 \times 10^{5}$ & 5.1 & $5.55 \times 10^{4}$ & 2.4 \\
\hline Orba 4 & 6.5 & 22.5 & 5.2 & $1.23 \times 10^{5}$ & 5.4 & $5.84 \times 10^{4}$ & 2.6 \\
\hline $\begin{array}{l}\text { weighted } \\
\text { mean }\end{array}$ & 6.8 & 17.7 & 4.8 & $1.22 \times 10^{5}$ & 5.4 & $5.81 \times 10^{4}$ & 2.6 \\
\hline \multicolumn{8}{|c|}{ April 2017} \\
\hline \multicolumn{8}{|l|}{ Arrestra } \\
\hline Arrestra 1 & 17.1 & 54.2 & 17.1 & $3.38 \times 10^{5}$ & 14.9 & $1.42 \times 10^{5}$ & 6.3 \\
\hline Arrestra 2 & 42.6 & 125 & 40.0 & $9.45 \times 10^{5}$ & 41.6 & $4.71 \times 10^{5}$ & 20.7 \\
\hline Arrestra 3 & 27.8 & 11.9 & 18.3 & $1.12 \times 10^{6}$ & 49.4 & $4.18 \times 10^{5}$ & 18.4 \\
\hline $\begin{array}{l}\text { weighted } \\
\text { mean } \\
\text { Teiro }\end{array}$ & 25.0 & 81.2 & 22.0 & $5.91 \times 10^{5}$ & 26.0 & $2.69 \times 10^{5}$ & 11.8 \\
\hline Teiro 1 & 51.7 & 174.5 & 74.9 & $9.37 \times 10^{5}$ & 41.2 & $2.45 \times 10^{5}$ & 10.6 \\
\hline Teiro 2 & 4.3 & 11.1 & 1.0 & $8.35 \times 10^{4}$ & 3.7 & $4.17 \times 10^{4}$ & 1.8 \\
\hline Teiro 3 & 6.7 & 67.4 & 21.1 & $4.97 \times 10^{5}$ & 21.9 & $1.56 \times 10^{5}$ & 6.8 \\
\hline $\begin{array}{l}\text { weighted } \\
\text { mean }\end{array}$ & 10.6 & 55.3 & 19.8 & $3.48 \times 10^{5}$ & 15.3 & $1.15 \times 10^{5}$ & 5.0 \\
\hline \multicolumn{8}{|l|}{ mean } \\
\hline Orba 1 & 50.0 & 73.0 & 19.15 & $4.90 \times 10^{5}$ & 21.5 & $2.04 \times 10^{5}$ & 9.0 \\
\hline Orba 2 & 18.7 & 37.2 & 11.9 & $2.16 \times 10^{5}$ & 9.5 & $1.06 \times 10^{5}$ & 4.6 \\
\hline Orba 3 & 13.7 & 24.3 & 5.0 & $1.62 \times 10^{5}$ & 7.1 & $7.80 \times 10^{4}$ & 3.4 \\
\hline Orba 4 & 13.5 & 11.4 & 8.8 & $1.13 \times 10^{5}$ & 5 & $5.66 \times 10^{4}$ & 2.5 \\
\hline $\begin{array}{l}\text { weighted } \\
\text { mean }\end{array}$ & 15.5 & 23.6 & 8.4 & $1.62 \times 10^{5}$ & 7.1 & $8.03 \times 10^{4}$ & 3.5 \\
\hline
\end{tabular}

The values of runoff for the ten sub-basins of the study area range from 1.7 to $21.3 \mathrm{~L} \mathrm{~s}^{-1} \mathrm{~km}^{-2}$ for the July 2016 campaign (7.2 $\mathrm{L} \mathrm{s}^{-1} \mathrm{~km}^{-2}$ on average) and from 4.3 to $50 \mathrm{~L} \mathrm{~s}^{-1} \mathrm{~km}^{-2}$ for the April 2017 campaign (17.0 $\mathrm{L} \mathrm{s}^{-1} \mathrm{~km}^{-2}$ on average). Considering the weighted mean of each basin, the runoff 
values vary within smaller intervals, ranging from 6.8 to $7.5 \mathrm{~L} \mathrm{~s}^{-1} \mathrm{~km}^{-2}$ during the dry season (July 2016) and from 10.6 to $25 \mathrm{~L} \mathrm{~s}^{-1} \mathrm{~km}^{-2}$ during the wet season (April 2017). All these values fall in the range computed for the basins of the Alpine region (from 0.7 to $45.4 \mathrm{~L} \mathrm{~s}^{-1} \mathrm{~km}^{-2}$ [23]).

In July 2016, the solute fluxes varied from 8.1 to $82.8 \mathrm{t} \mathrm{km}^{-2} \mathrm{y}^{-1}$ and the weathering rates varied from 1.7 to $21.3 \mathrm{t} \mathrm{km}^{-2} \mathrm{y}^{-1}$, while in April 2017 the solute fluxes varied from 11.9 to $174.5 \mathrm{t} \mathrm{km}^{-2} \mathrm{y}^{-1}$ and the weathering rates from 4.3 to $50 \mathrm{t} \mathrm{km}^{-2} \mathrm{y}^{-1}$.

Weathering rate is always lower than the solute flux, because the latter comprises also the atmospheric/rain component. Both the parameters are higher during the wet season than during the dry season. On average, about $33 \% \pm 12 \%$ of the solute fluxes derives from rock dissolution (mostly silicates), $55 \% \pm 4 \%$ is constituted by dissolved carbon species, mainly bicarbonates, and $12 \% \pm 7 \%$ derives from other rain/atmospheric components. Practically all the dissolved species of inorganic carbon derive from the dissolution of atmospheric/soil $\mathrm{CO}_{2}$, except for the Teiro basin where $23 \% \pm 5 \%$ of $\mathrm{HCO}_{3}$ in solution derives from the dissolution of calcite.

Similarly to the weathering rates, also the $\mathrm{CO}_{2}$ consumed by weathering is higher during the wet season: $\mathrm{FCO}_{2}$-short range from $5.96 \times 10^{4}$ to $5.84 \times 10^{5} \mathrm{~mol} \mathrm{~km}^{-2} \mathrm{y}^{-1}$ with a weighted average of $3.24 \times$ $10^{5} \mathrm{~mol} \mathrm{~km}^{-2} \mathrm{y}^{-1}$ in July 2016 and from $8.35 \times 104$ to $1.12 \times 10^{6} \mathrm{~mol} \mathrm{~km}^{-2} \mathrm{y}^{-1}$ with a weighted average of $3.67 \times 10^{5} \mathrm{~mol} \mathrm{~km}^{-2} \mathrm{y}^{-1}$ in April 2017; $F \mathrm{CO}_{2}$-long range from $2.25 \times 10^{4}$ to $2.72 \times 10^{5} \mathrm{~mol} \mathrm{~km}^{-2} \mathrm{y}^{-1}$ with a weighted average of $9.46 \times 10^{4} \mathrm{~mol} \mathrm{~km}^{-2} \mathrm{y}^{-1}$ in July 2016 and from $4.17 \times 10^{4}$ to $4.71 \times$ $10^{5} \mathrm{~mol} \mathrm{~km}^{-2} \mathrm{y}^{-1}$ with an average of $1.55 \times 10^{5} \mathrm{~mol} \mathrm{~km}^{-2} \mathrm{y}^{-1}$ in April 2017.

\section{Discussion}

On the short term, the amount of carbon dioxide consumed by the weathering of the ultramafic rocks of the Voltri Massif (average $F \mathrm{FO}_{2}$-short $=3.02 \pm 1.67 \times 10^{5} \mathrm{~mol} \mathrm{~km}^{-2} \mathrm{y}^{-1}$, considering both the dry and the wet season) is slightly higher than the world average $\mathrm{CO}_{2}$ consumption rate $\left(2.46 \times 10^{5} \mathrm{~mol} \mathrm{~km}^{-2} \mathrm{y}^{-1}[21]\right)$, fall in the range of the $F \mathrm{FO}_{2}$-short values of the Alpine region (from $2.68 \times 10^{4} \mathrm{~mol} \mathrm{~km}^{-2} \mathrm{y}^{-1}$ to $2.04 \times 10^{6} \mathrm{~mol} \mathrm{~km}^{-2} \mathrm{y}^{-1}$ [23]) and it is very close to the global average $\mathrm{CO}_{2}$ consumption rate of basic, plutonic and volcanic rocks $\left(3.18 \times 10^{5} \mathrm{~mol} \mathrm{~km}^{-2} \mathrm{y}^{-1}\right.$ and $2.68 \times$ $10^{5} \mathrm{~mol} \mathrm{~km}^{-2} \mathrm{y}^{-1}$ respectively [81]).

On the long term, the $\mathrm{CO}_{2}$ consumption rates of the Voltri Massif are definitely higher than the $\mathrm{CO}_{2}$ consumption rates of hydrologic basins with similar climatic conditions but different lithologies. For example, the values of $\mathrm{FCO}_{2}$-long of the Voltri Massif basins are one order of magnitude higher than $\mathrm{FCO}_{2}$-long values computed for the nearby Alpine region [23]. This difference is very significant because the Alpine region, characterized by similar runoff values but different outcropping lithologies, roughly approximate the world lithological distribution [23,82]. $\mathrm{FCO}_{2}$-long in the Voltri Massif is, on average, $42 \% \pm 0.8 \%$ of $\mathrm{FCO}_{2}$-short, while in the Alps is only $5 \%$ (Figure $6 \mathrm{a}$ ). In other words, the two regions consume similar amounts of carbon dioxide per unit area on the short term but, while a large part of $\mathrm{CO}_{2}$ consumed by weathering in the Alpine region is returned to the atmosphere within one million year [23], more than $40 \%$ of the atmospheric $\mathrm{CO}_{2}$ consumed by the weathering of Voltri Massif ophiolites is removed from the atmosphere almost permanently (for tens to hundreds million years).

Ultramafic rocks occupy a relatively small fraction of Earth's total exposed surface and the rate of $\mathrm{CO}_{2}$ uptake via weathering of ultramafic rocks is poorly known in natural conditions. The few data available clearly highlight that they have the highest potential to capture atmospheric $\mathrm{CO}_{2}$ on the long term (e.g., about $10^{4}$ to $10^{5}$ tons of atmospheric $\mathrm{CO}_{2}$ per year are converted to solid carbonates from an area of about $350 \times 40 \mathrm{~km}^{2}$ in the Samail ophiolite (Oman), with a corresponding $\mathrm{CO}_{2}$ consumption flux between $10^{5}$ and $10^{6} \mathrm{~mol} \mathrm{~km}^{-2} \mathrm{y}^{-1}$ [37]; Zambales and Angat ophiolites (Luzon Island, the Philippines) are characterized by an extremely high rate of $\mathrm{CO}_{2}$ sequestration $\left(2.9 \times 10^{6} \mathrm{~mol} \mathrm{~km}^{-2} \mathrm{y}^{-1}\right.$ [83], more than one order of magnitude higher than the average terrestrial $\mathrm{CO}_{2}$ consumption rate [21]). The $\mathrm{CO}_{2}$ consumption rates of the Voltri Massif are in the range of the Samail ophiolite, but lower than those of Zambales and Angat. However, they show a similar $\mathrm{FCO}_{2} /$ runoff ratio both in the long and in the short term. The high carbon sequestration flux of Zambales and Angat ophiolites, with respect to 
Voltri Massif, is primarily due to the very high runoff $\left(78 \mathrm{~L} \mathrm{~km}^{-2} \mathrm{y}^{-1}\right)$, almost one order of magnitude higher than runoff in Voltri Massif, indicating that runoff is probably the most important weathering controlling factor.

In order to assess the relationships between $\mathrm{FCO}_{2}$-short, $\mathrm{FCO}_{2}$-long, weathering rate and the potential controlling factors, runoff, temperature, flow rate, and elevation, we computed the Pearson's product-moment correlation coefficient, $r$ [84,85], for each pair of variables (Table 5). $\mathrm{FCO}_{2}$-short, weathering rate and to a lesser extent $\mathrm{FCO}_{2}$-long are positively correlated with runoff, practically not correlated with temperature and flow rate, and show a poor negative correlation with altitude.

Table 5. Pearson correlation matrix of $\mathrm{FCO}_{2}$ (fluxes of atmospheric carbon dioxide consumed by weathering in the short and long term), weathering rates and controlling factors: runoff, temperature, flow rate, and altitude.

\begin{tabular}{|c|c|c|c|c|c|c|c|}
\hline & $\mathrm{FCO}_{2}$-Short & $\mathrm{FCO}_{2}$-Long & Weathering Rate & Runoff & Temperature & Flow Rate & Altitude \\
\hline $\mathrm{FCO}_{2}$-short & 1.000 & 0.938 & 0.762 & 0.707 & -0.140 & 0.247 & -0.561 \\
\hline $\mathrm{FCO}_{2}$-long & & 1.000 & 0.588 & 0.674 & -0.145 & 0.251 & -0.512 \\
\hline Weathering Rate & & & 1.000 & 0.694 & -0.067 & -0.008 & -0.358 \\
\hline Runoff & & & & 1.000 & -0.541 & -0.002 & 0.094 \\
\hline Temperature & & & & & 1.000 & -0.308 & -0.398 \\
\hline Flow rate & & & & & & 1.000 & -0.305 \\
\hline Altitude & & & & & & & 1.000 \\
\hline
\end{tabular}

The significant correlations of weathering rates and $\mathrm{FCO}_{2}$ with runoff, indicate the strong dependence of $\mathrm{CO}_{2}$ consumption on the intensity of the hydrological cycle. Runoff, being the difference between rainfall, infiltration, and evapotranspiration, reflects a number of climatic, biologic and geologic variables and plays a pivotal role in weathering and $\mathrm{CO}_{2}$ consumption both on the long and short term $[3,23]$. In particular, the large variations of $\mathrm{FCO}_{2}$-short with runoff shown by our data (6.b) suggest that weathering of ultramafic rocks might also play a significant role on human time scales (centuries, decades). The hydrologic response to global warming is still debated: many studies show that runoff decreases with temperature increase in rainfall-dominated basins [86-88] but some recent works suggest that global warming would lead to a runoff increase, at least in the catchments where runoff is related, or partly related, to ice and snow melting $[10,11,89]$. In both cases the variation of surface runoff might produce a rapid feedback (positive or negative) on weathering rates and $\mathrm{CO}_{2}$ consumption suggesting that the relationships between runoff and consumption of atmospheric $\mathrm{CO}_{2}$ then should be taken into account in climate models.
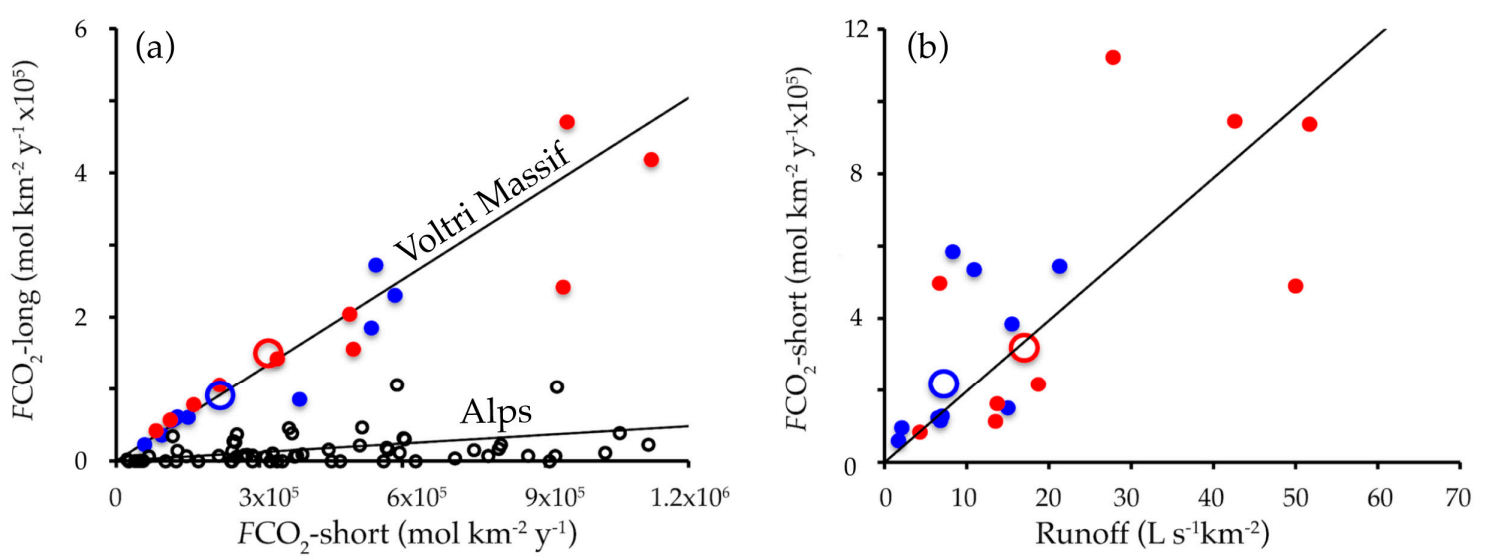

Figure 6. (a) $\mathrm{FCO}_{2}$-long vs. $\mathrm{FCO}_{2}$-short diagram. Red full circles indicate samples collected during the wet season, blue full circles indicate samples collected during the dry season; open circles indicate the weighted averages of the wet (red) and dry (blue) seasons. The samples of Voltri Massif are compared to the samples of the Alps (open black circles [23]). (b) $\mathrm{FCO}_{2}$-short vs. runoff diagram. 
It is generally assumed that weathering increases with runoff and temperature but in the Mediterranean region, and in most of mid-latitude climatic zones characterized by rainy winters and dry summers, these two variables show opposite trends. In temperate Mediterranean climates, runoff, the stronger weathering controlling factor, is higher during the wet, colder, season. This consideration justifies the absence of correlation of weathering rates and $F-\mathrm{CO}_{2}$ with temperature observed in the basins of the Voltri Massif (Table 5).

With the aim to evaluate the influence of temperature on $\mathrm{CO}_{2}$ consumption, we computed the $\mathrm{FCO}_{2}$-short/runoff and $\mathrm{FCO}_{2}$-long/runoff ratios $\left(R_{\text {short }}\right.$ and $\left.R_{\text {long }}\right)$ considering the weighted averages of $F \mathrm{CO}_{2}$ and runoff of the three studied basins. $R_{\text {short }}$ and $R_{\text {long, }}$, computed both in the dry and wet seasons, practically are the amounts of atmospheric $\mathrm{CO}_{2}$ removed by one liter of water $\left(\mathrm{mol} \mathrm{L}^{-1}\right)$ multiplied by a constant $\left(3.1556 \times 10^{7}\right)$ representing the number of seconds in one solar year. In order to expand the investigated temperature interval, the same ratios have been computed also for the Zambales and Angat areas, characterized by a mean annual temperature of $27.5^{\circ} \mathrm{C}$.

Figure 7a,b shows that both $R_{\text {short }}$ and $R_{\text {long }}$ increase exponentially with temperature. The regression equations $\left(R_{\text {short }}=5 \times 10^{-6} \times \mathrm{e}^{0.0778 \mathrm{~T}} ; R_{\text {long }}=2 \times 10^{-6} \times \mathrm{e}^{0.0781 \mathrm{~T}}\right)$ have good coefficients of determination $\left(r^{2}=0.6821\right.$ and $r^{2}=0.7001$ respectively) and allow us to find the relationships between temperature and $\mathrm{CO}_{2}$ consumption rates of ultramafic rocks. The fluxes of atmospheric carbon dioxide consumed by weathering in the short and long term are given by $R_{\text {short }}$ and $R_{\text {long }}$ multiplied by runoff $\left(\mathrm{L} \mathrm{s}^{-1} \mathrm{~km}^{-2}\right)$ :

$$
\mathrm{FCO}_{2} \text {-short }=\text { runoff } \times R_{\text {short }}=\text { runoff } \times 5 \times 10^{-6} \times \mathrm{e}^{0.0778 \mathrm{~T}}
$$

and

$$
\mathrm{FCO}_{2} \text {-long }=\text { runoff } \times R_{\text {long }}=\text { runoff } \times 2 \times 10^{-6} \times \mathrm{e}^{0.0781 \mathrm{~T}}
$$

where $\mathrm{T}$ is in kelvin, runoff is given in $\mathrm{L} \mathrm{s}^{-1} \mathrm{~km}^{-2}$ and $\mathrm{FCO}_{2}$ is in $\mathrm{mol} \mathrm{km} \mathrm{y}^{-2}$.
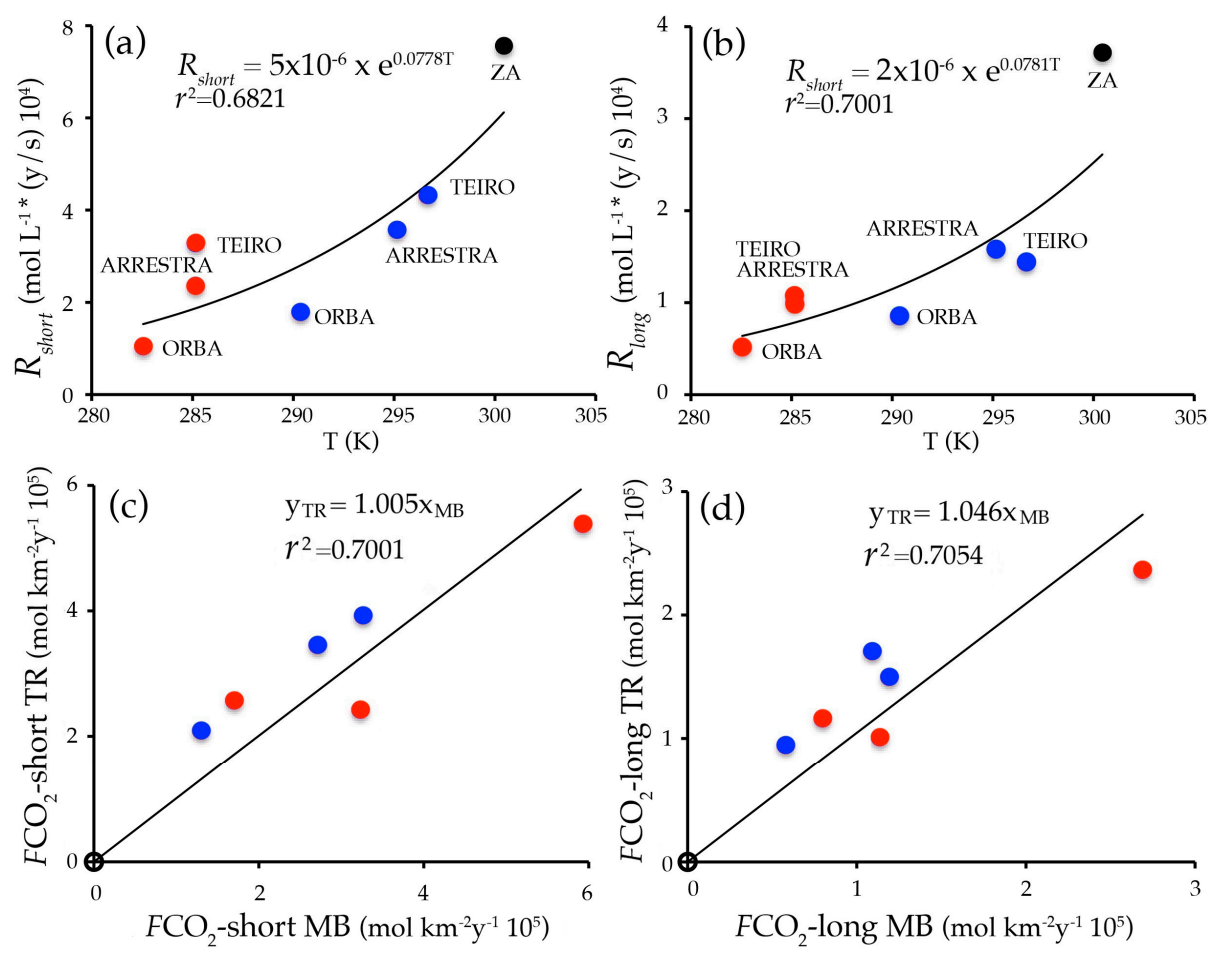

Figure 7. $R_{\text {short }}$ vs. T (a) and $R_{\text {long }}$ vs. T (b) diagrams. Red full circles indicate wet season, blue full circles indicate the dry season, ZA stands for Zambales and Angat ophiolites; (c) comparison of the $\mathrm{FCO}_{2}$-short values computed from the temperature regression (TR) of Equation (11) and the geochemical mass balance (MB); (d) comparison of the $\mathrm{FCO}_{2}$-long values computed from the temperature regression (TR) of Equation (12) and the geochemical mass balance (MB). 
The proposed equations are based on a relatively small amount of data and need further studies, possibly in different climatic regions, to be better constrained. However, a first assessment of the goodness of the proposed equations can be done by comparing the $\mathrm{FCO}_{2}$-short and $\mathrm{FCO}_{2}$-long values derived from Equations (11) and (12) to the same variables computed from the geochemical mass balances of Equations (7) and (8). The two sets of data are well correlated and plot near the 1:1 line both in the short term (Figure 7c) and in the long term (Figure 7d). The differences between the $\mathrm{CO}_{2}$ consumption rates computed with the two methods are, on average, $14 \%$ for $\mathrm{FCO}_{2}$-short and $16 \%$ for $\mathrm{FCO}_{2}$-long. These differences are very small considering that $\mathrm{CO}_{2}$ consumption fluxes may vary over orders of magnitude.

\section{Conclusions}

Chemical weathering of ultramafic rocks is one of the most important sinks for atmospheric $\mathrm{CO}_{2}$ over geologic time $[33,34]$. Weathering rates and carbon dioxide consumption are linked to a complex combination of lithology, runoff, and temperature, and it is difficult to isolate the effects of each single variable on a global scale. Global $\mathrm{CO}_{2}$ consumption is generally estimated from the geochemical mass balance of large river systems [21-23] or from parametric models based on global lithological maps and on the spatial correlation between runoff, lithology, and $F \mathrm{CO}_{2}[19,24,77,78]$. The study of small mono lithology river basins can be used to calibrate high resolution global models and to shed light on the relationships between $\mathrm{FCO}_{2}$ and controlling parameters (i.e. runoff and temperature). Furthermore, the knowledge of the carbon dioxide consumption rates in natural settings could be useful for the study of the geological sequestration of $\mathrm{CO}_{2}$ through mineral carbonation reactions $[35,36]$ and enhanced weathering [90].

The hydrogeochemical mass balances of the Voltri Massif river basins, almost completely composed of ophiolites and meta-ophiolites show that in the short term the specific flux of $\mathrm{CO}_{2}$ consumed by weathering per unit area $\left(\mathrm{FCO}_{2}\right.$-short $)$ is higher than the global average $\mathrm{CO}_{2}$ consumption rate and, in the long term, $\mathrm{FCO}_{2}$-long is almost one order of magnitude higher than the global average $\mathrm{CO}_{2}$ removal rate: about $42 \%$ of the $\mathrm{CO}_{2}$ consumed by the weathering reactions in the Voltri Massif is permanently removed from the atmosphere via carbonate precipitation in the oceans.

At the present many studies on the weathering of ultramafic rock are focused on tropical and sub-tropical regions where the favorable combination of high temperatures and very high runoff values produces extremely high rates of carbon dioxide removal [81,83]. However, many large outcrops of ultramafic rocks are located in the Mediterranean region and in other regions of the world characterized by temperate and Mediterranean climates [91]. Among them, we can mention the Jurassic ophiolites of the Apennines and Alps, the late Cretaceous Troodos Ophiolite on the island of Cyprus, the Jurassic Coast Range Ophiolite in California, and the Permian Dun Mountain Ophiolite in New Zealand's South Island. The results of our study, together with the distribution in space of ophiolite belts and other ultramafic rocks, suggest that also in temperate and Mediterranean climatic regions, ultramafic rocks can contribute significantly to atmospheric $\mathrm{CO}_{2}$ consumption on a global scale in both the short and long term.

Furthermore, the rapid response of weathering and $\mathrm{CO}_{2}$ consumption rates to runoff variations suggests that weathering of ultramafic rocks could produce an effective feedback mechanism on climate change. In particular, at mid latitudes where temperature and runoff show opposite trends and runoff may be partly related to snow melting (as observed in the Voltri Massif), runoff might increase with the temperature increase and as a result, weathering of ultramafic rocks would remove larger amounts of carbon dioxide from the atmosphere acting as a negative climate feedback.

Supplementary Materials: The following material is available online at http://www.mdpi.com/2076-3263/9/6/258/ s1, Table S1: field data, Table S2: chemical and isotopic composition of stream waters.

Author Contributions: Conceptualization, F.F. and M.V.Z.; methodology, F.F.; software, M.V.Z.; validation, F.F., O.V., and M.V.Z.; formal analysis, F.F., and M.V.Z; investigation, F.F., O.V., and M.V.Z; data curation, M.V.Z; writing-original draft preparation, F.F, O.V. and M.V.Z.; supervision F.F. 
Funding: This research was partly funded by Università degli Studi di Perugia, Dipartimento di Fisica e Geologia, project DIP11FF.

Acknowledgments: We would like to thank Enricomaria Selmo (Università di Parma) for the analyses of hydrogen and oxygen isotopes and Gianluca Polidori (Università di Perugia) for the technical support during chemical analyses. We thank the anonymous reviewers for their many useful comments and suggestions.

Conflicts of Interest: The authors declare no conflict of interest.

\section{References}

1. Brady, P.V. The effect of silicate weathering on global temperature and atmospheric $\mathrm{CO}_{2}$. J. Geophys. Res. Solid Earth 1991, 96, 18101-18106. [CrossRef]

2. Kump, L.R.; Arthur, M.A. Global chemical erosion during the Cenozoic: Weatherability balances the budgets. In Tectonic Uplift and Climate Change; Ruddiman, W.F., Ed.; Plenum Press: New York, NY, USA, 1997; pp. 399-426.

3. Kump, L.R.; Brantley, S.L.; Knoll, M.A. Chemical weathering, atmospheric $\mathrm{CO}_{2}$, and climate. Annu. Rev. Earth Planet. Sci. 2000, 28, 611-667. [CrossRef]

4. Kump, L.R.; Kasting, J.F.; Crane, R.G. The Earth System, 3rd ed.; Prentice Hall: Upper Saddle River, NJ, USA, 2009; p. 432.

5. Tipper, E.T.; Bickle, M.J.; Galy, A.; West, A.J.; Pomiès, C.; Chapman, H.J. The short term climatic sensitivity of carbonate and silicate weathering fluxes: Insight from seasonal variations in river chemistry. Geochim. Cosmochim. Acta 2006, 70, 2737-2754. [CrossRef]

6. White, A.F.; Brantley, S.L. The effect of time on the weathering of silicate minerals: Why do weathering rates differ in the laboratory and field? Chem. Geol. 2003, 202, 479-506. [CrossRef]

7. Broecker, W.; Yu, J. What do we know about the evolution of Mg to Ca ratios in seawater? Paleoceanography 2011, 26, PA3203. [CrossRef]

8. Berner, R.A.; Lasaga, A.C.; Garrels, R.M. The carbonate-silicate geochemical cycle and its effect on atmospheric carbon dioxide over the past 100 million years. Am. J. Sci. 1983, 283, 641-683. [CrossRef]

9. Raymond, P.A.; Oh, N.-H.; Turner, R.E.; Broussard, W. Anthropogenic enhanced fluxes of water and carbon from the Mississippi River. Nature 2008, 451, 449-452. [CrossRef] [PubMed]

10. Gislason, S.R.; Oelkers, E.H.; Eiriksdottir, E.S.; Kardjilov, M.I.; Gisladottir, G.; Sigfusson, B.; Snorrason, A.; Elefsen, S.; Hardardottir, J.; Torssander, P.; et al. Direct evidence of the feedback between climate and weathering. Earth Planet. Sci. Lett. 2009, 277, 213-222. [CrossRef]

11. Beaulieu, E.; Goddéris, Y.; Donnadieu, Y.; Labat, D.; Roelandt, C. High sensitivity of the continental-weathering carbon dioxide sink to future climate change. Nat. Clim. Chang. 2012, 2, 346-349. [CrossRef]

12. Garrels, R.M.; Mackenzie, F.T. Evolution of Sedimentary Rocks; Norton \& Co.: New York, NY, USA, $1971 ;$ p. 397.

13. Drever, J.I. The Geochemistry of Natural Waters; Prentice-Hall: Englewood Cliffs, NJ, USA, 1982; p. 388.

14. Berner, E.K.; Berner, R.A. The Global Water Cycle. Geochemistry and Environment; Prentice Hall: Engelwood Cliffs, NJ, USA, 1987; p. 397.

15. Probst, J.L.; Mortatti, J.; Tardy, Y. Carbon river fluxes and global weathering $\mathrm{CO}_{2}$ consumption in the Congo and Amazon River Basins. Appl. Geochem. 1994, 9, 1-13. [CrossRef]

16. Meybeck, M. Global occurrence of major elements in rivers. In Surface and Ground Water, Weathering, and Soils. Treatise on Geochemistry; Drever, J.I., Ed.; Elsevier: Oxford, UK, 2003; Volume 5, pp. 207-224.

17. Bricker, O.P.; Jones, B.F.; Bowser, C.J. Mass-balance Approach to Interpreting Weathering Reactions in Watershed Systems. In Surface and Ground Water, Weathering, and Soils. Treatise on Geochemistry; Drever, J.I., Ed.; Elsevier: Oxford, UK, 2003; Volume 5, pp. 119-132.

18. Meybeck, M. Global chemical weathering of surficial rocks estimated from river dissolved load. Am. J. Sci. 1987, 287, 401-428. [CrossRef]

19. Amiotte-Suchet, P.; Probst, J.L. A global model for present day atmospheric $\mathrm{CO}_{2}$ consumption by chemical erosion of continental rocks (GEM CO 2 ). Tellus 1995, 47, 273-280. [CrossRef]

20. Boeglin, J.L.; Probst, J.L. Physical and chemical weathering rates and $\mathrm{CO}_{2}$ consumption, in a tropical lateritic environment: The upper Niger basin. Chem. Geol. 1998, 148, 137-156. [CrossRef]

21. Gaillardet, J.; Dupré, B.; Louvat, P.; Allègre, C.J. Global silicate weathering and $\mathrm{CO}_{2}$ consumption rates deduced from the chemistry of large rivers. Chem. Geol. 1999, 159, 3-30. [CrossRef] 
22. Mortatti, J.; Probst, J.L. Silicate rock weathering and atmospheric/soil $\mathrm{CO}_{2}$ uptake in the Amazon Basin estimated from river water geochemistry: Seasonal and spatial variations. Chem. Geol. 2003, 197, 177-196. [CrossRef]

23. Donnini, M.; Frondini, F.; Probst, J.L.; Probst, A.; Cardellini, C.; Marchesini, I.; Guzzetti, F. Chemical weathering and consumption of atmospheric carbon dioxide in the Alpine region. Glob. Planet. Chang. 2016, 136, 65-81. [CrossRef]

24. Amiotte-Suchet, P.; Probst, J.L. Flux de $\mathrm{CO}_{2}$ consommé par altération chimique continentale: Influences du drainage et de la lithologie. C. R. Acad. Sci. Paris II Méc. Phys. Chim. Astron. 1993, 317, 615-622.

25. Bluth, G.J.S.; Kump, L.R. Lithological and climatological controls of river chemistry. Geochim. Cosmochim. Acta 1994, 58, 2341-2359. [CrossRef]

26. Gislason, S.R.; Arnorsson, S.; Armansson, H. Chemical weathering of basalt in south-west Iceland: Effects of runoff, age of rocks and vegetative/glacial cover. Am. J. Sci. 1996, 296, 837-907. [CrossRef]

27. Louvat, P.; Allègre, C.J. Present denudation rates at Réunion Island determined by river geochemistry: Basalt weathering and mass budget between chemical and mechanical erosions. Geochim. Cosmochim. Acta 1997, 61, 3645-3669. [CrossRef]

28. White, A.F. Natural weathering rates of silicate minerals. In Surface and Ground Water, Weathering, and Soils. Treatise on Geochemistry; Drever, J.I., Ed.; Elsevier: Oxford, UK, 2003; Volume 5, pp. 133-168.

29. Swoboda-Colberg, N.G.; Drever, J.I. Mineral dissolution rates in plot-scale field and laboratory experiments. Chem. Geol. 1993, 105, 51-69. [CrossRef]

30. White, A.F.; Brantley, S.L. Chemical weathering rates of silicate minerals: An overview. In Chemical Weathering Rates of Silicate Minerals, Review in Mineralogy; White, A.F., Brantley, S.L., Eds.; Mineralogical Society of America: Chantilly, VA, USA, 1995; Volume 31, pp. 1-22.

31. Reeves, D.; Rothman, D.H. Age dependence of mineral dissolution and precipitation rates. Glob. Biogeochem. Cycles 2013, 27, 906-919. [CrossRef]

32. Gruber, C.; Zhu, C.; Georg, R.B.; Zakon, Y.; Ganor, J. Resolving the gap between laboratory and field rates of feldspar weathering. Geochim. Cosmochim. Acta 2014, 147, 90-106. [CrossRef]

33. Berner, R.A. The long-term carbon cycle, fossil fuels and atmospheric composition. Nature 2003, 426, 323-326. [CrossRef] [PubMed]

34. Beinlich, A.; Austrheim, H.; Mavromatis, V.; Grguric, B.; Putnis, C.V.; Putnis, A. Peridotite weathering is the missing ingredient of Earth's continental crust composition. Nat. Commun. 2018, 9, 634. [CrossRef]

35. Cipolli, F.; Gambardella, B.; Marini, L.; Ottonello, G.; Vetuschi Zuccolini, M. Geochemistry of high-pH waters from serpentinites of the Gruppo di Voltri (Genova, Italy) and reaction path modeling of $\mathrm{CO}_{2}$ sequestration in serpentinite aquifers. Appl. Geochem. 2004, 19, 787-802. [CrossRef]

36. Marini, L. Geological Sequestration of Carbon Dioxide: Thermodynamics, Kinetics, and Reaction Path Modeling; Developments in Geochemistry 11; Elsevier: Oxford, UK, 2007; p. 453.

37. Kelemen, P.B.; Matter, J. In situ carbonation of peridotite for $\mathrm{CO}_{2}$ storage. Proc. Natl. Acad. Sci. USA 2008, 105, 17295-17300. [CrossRef]

38. Regione Liguria. Geoportale, Litologia and CARG maps. Available online: https://geoportal.regione.liguria. it/mappe (accessed on 5 February 2019).

39. Capponi, G.; Crispini, L.; Federico, L.; Malatesta, C. Geology of the Eastern Ligurian Alps: A review of the tectonic units. Ital. J. Geosci. 2016, 135, 157-169. [CrossRef]

40. Gelati, R.; Gnaccolini, M. Synsedimentary tectonics and sedimentation in the Tertiary Piedmont Basin, Northwestern Italy. Riv. It. Paleont. Strat. 1998, 104, 193-214.

41. Mutti, E.; Papani, L.; Di Biase, D.; Davoli, G.; Mora, S.; Segadelli, S.; Tinterri, R. Il Bacino Terziario Epimesoalpino e le sue implicazioni sui rapporti tra Alpi e Appennino. Memorie Scienze Geologiche 1995, 47, 217-244.

42. Maino, M.; Decarlis, A.; Felletti, F.; Seno, S. Tectono-sedimentary evolution of the Tertiary Piedmont Basin (NW Italy) within the Oligo-Miocene central Mediterranean geodynamics. Tectonics 2013, 2, 593-619. [CrossRef]

43. Federico, L.; Crispini, L.; Malatesta, C.; Torchio, S.; Capponi, G. Geology of the Pontinvrea area (Ligurian Alps, Italy): Structural setting of the contact between Montenotte and Voltri units. J. Maps 2015, 11, 101-113. [CrossRef] 
44. Vanossi, M.; Cortesogno, L.; Galbiati, B.; Messiga, B.; Piccardo, G.; Vannucci, R. Geologia delle Alpi Liguri: Dati, problemi, ipotesi. Mem. Soc. Geol. Ital. 1986, 28, 5-75.

45. Chiesa, S.; Cortesogno, L.; Forcella, F.; Galli, M.; Messiga, B.; Pasquare, G.; Pedemonte, G.M.; Piccardo, G.B. Assetto strutturale ed interpretazione geodinamica del Gruppo di Voltri. Bol. Soc. Geol. It. 1975, 94, 555-581.

46. Treble, P.J. The Voltri Group, Northern Italy: An Alpine ophiolite massif. In Evolution of Metamorphic Belts; Daly, J.S., Cliff, R.A., Yardley, B.W.D., Eds.; Geological Society: London, UK, 1989; Volume 43, pp. 551-556.

47. Stampfli, G.M.; Vavassis, I.; De Bono, A.; Rosselet, F.; Matti, B.; Bellini, M. Remnants of the Paleotethys oceanic suture-zone in the western Tethyan area. Bol. Soc. Geol. It. 2003, 2, 1-23.

48. Piccardo, G.B. The Jurassic Ligurian Tethys, a fossil ultraslow-spreading ocean: The mantle perspective. In Metasomatism in Oceanic and Continental Lithospheric Mantle; Coltorti, M., Grégoire, M., Eds.; Geological Society: London, UK, 2008; Volume 293, pp. 11-34.

49. Piccardo, G.B.; Padovano, M.; Guarnieri, L. The Ligurian Tethys: Mantle processes and geodynamics. Earth-Sci. Rev. 2014, 138, 409-434. [CrossRef]

50. Piccardo, G.B. Le ofioliti dell'areale ligure: Petrologia e ambiente geodinamico di formazione (relazione ufficiale). Ofioliti 1976, 1, 469-500.

51. Piccardo, G.B. Le ofioliti metamorfiche del Gruppo di Voltri, Alpi Liguri: Caratteri primari e interpretazione geodinamica. Mem. Soc. Geol. It. 1984, 28, 95-114.

52. Messiga, B.; Scambelluri, M. Retrograde P-T-t path for the Voltri Massif eclogites (Ligurian Alps, Italy): Some tectonic implications. J. Metamorph. Geol. 1991, 9, 93-109. [CrossRef]

53. Crispini, L.; Capponi, G. Tectonic evolution of the Voltri Group and Sestri Voltaggio zone (southern limit of the NW Alps): A review. Ofioliti 2001, 26, 161-164.

54. Vignaroli, G.; Rossetti, F.; Rubatto, D.; Theye, T.; Lisker, F.; Phillips, D. Pressure-temperature-deformation-time (P-T-d-t) exhumation history of the Voltri Massif HP complex, Ligurian Alps, Italy. Tectonics 2010, 29, TC6009. [CrossRef]

55. Seno, S.; Dallagiovanna, G.; Vanossi, M. A kinematic evolution model for the Penninic sector of the central Ligurian Alps. Int. J. Earth Sci. 2005, 94, 114-129. [CrossRef]

56. Capponi, G.; Crispini, L. Structural and metamorphic signature of Alpine tectonics in the Voltri Massif (Ligurian Alps, northwestern Italy). Ecl. Geol. Helv. 2002, 95, 31-42.

57. Federico, L.; Capponi, G.; Crispini, L.; Scambelluri, M.; Villa, I.M. 39Ar/40Ar dating of high pressure rocks from the Ligurian Alps: Evidence for a continuous subduction-exhumation cycle. Earth Planet. Sci. Lett. 2005, 240, 668-680. [CrossRef]

58. Speranza, F.; Villa, I.M.; Sagnotti, L.; Florindo, F.; Cosentino, D.; Cipollari, P.; Mattei, M. Age of the Corsica-Sardinia rotation and Liguro-Provençal Basin spreading: New paleomagnetic and Ar/Ar evidence. Tectonophysics 2002, 347, 231-251. [CrossRef]

59. Gattacceca, J.; Deino, A.; Rizzo, R.; Jones, D.S.; Henry, B.; Beaudoin, B.; Vadeboin, F. Miocene rotation of Sardinia: New paleomagnetic and geochronological constraints and geodynamic implications. Earth Planet. Sci. Lett. 2007, 258, 359-377. [CrossRef]

60. Firpo, M.; Piccazzo, M. Geomofologia. In Note Illustrative Della Carta Geologica d'Italia, Foglio 213-230 Genova; Capponi, G., Crispini, L., Eds.; APAT Servizio Geologico d'Italia: Ispra, Italy, 2013; pp. 99-106.

61. ARPAL. Atlante Climatico della Liguria; ARPAL: Genova, Italy, 2013; p. 128.

62. Bocchio, R. Chemical variations in clinopyroxenes and garnet from eclogites of the Vara Valley (Voltri Group), Italy. Eur. J. Mineral. 1995, 7, 103-117. [CrossRef]

63. Regione Liguria. Geoportale, DTM-Modello Digitale del Terreno-Liguria 2016. Available online: https://geoportal.regione.liguria.it (accessed on 15 December 2018).

64. Neteler, M.; Bowman, M.H.; Landa, M.; Metz, M. GRASS GIS: A multi-purpose open source GIS. Environ. Model. Softw. 2012, 31, 124-130. [CrossRef]

65. Amiotte-Suchet, P.; Probst, J.L. Modelling of atmospheric $\mathrm{CO}_{2}$ consumption by chemical weathering of rocks: Application to the Garonne, Congo and amazon basins. Chem. Geol. 1993, 107, 205-210. [CrossRef]

66. Ladouche, B.; Aquilina, L.; Dörfliger, N. Chemical and isotopic investigation of rainwater in Southern France (1996-2002): Potential use as input signal for karst functioning investigation. J. Hydrol. 2009, 367, 150-164. [CrossRef]

67. Celle, H. Caractérisation des Précipitations sur le Pourtour de la Méditerranée Occidentale-Approche Isotopique et Chimique. Ph.D. Thesis, University of Avignon, Avignon, France, 2000. 
68. Craig, H. Isotopic variations in meteoric waters. Science 1961, 133, 1702-1703. [CrossRef] [PubMed]

69. Longinelli, A.; Selmo, E. Isotopic composition of precipitation in Italy: A first overallmap. J. Hydrol. 2003, $270,75-88$

70. Marini, L.; Ottonello, G. (Eds.) Atlante Degli Acquiferi Della Liguria-Vol. III: Le Acque Dei Complessi Ofiolitici (Bacini Arrestra, Branega, Cassinelle, Cerusa, Erro, Gorzente, Leira, Lemme, Lerone, Orba, Piota, Polcevera, Rumaro, Sansobbia, Stura, Teiro, Varenna, Visone); Pacini Editore: Pisa, Italy, 2002.

71. Parkhurst, D.L. User's Guide to PHREEQC: A Computer Program. for Speciation, Reaction-Path, Advective-Transport., and Inverse Geochemical Calculations; Water-Resources Investigations Report 95-4227; U.S. Geological Survey, Earth Science Information Center, Open-File Reports Section: Lakewood, CO, USA, 1995; p. 143.

72. Wolery, T.J. Calculation of Chemical Equilibrium between Aqueous Solution and Minerals-The EQ3/6 Software Package; Lawrence Livermore National Laboratory Report UCRL-52658; Lawrence Livermore National Laboratory: Livermore, CA, USA, 1979; p. 41.

73. Bonifacio, E.; Zanini, E.; Boero, V.; Franchini-Angela, M. Pedogenesis in a soil catena on serpentinite in north-western Italy. Geoderma 1997, 75, 33-51. [CrossRef]

74. Reeder, R.J.; Nakajima, Y. The nature of ordering and ordering defects in dolomite. Phys. Chem. Miner. 1982, 8, 29-35. [CrossRef]

75. Zucchini, A.; Comodi, P.; Katerinopoulou, A.; Balic-Zunic, T.; McCammon, C.; Frondini, F. Order-disorder-reorder process in thermally treated dolomite samples: A combined powder and single-crystal X-ray diffraction study. Phys. Chem. Miner. 2012, 39, 319-328. [CrossRef]

76. Arvidson, R.S.; Mackenzie, F.T. The dolomite problem: Control of precipitation kinetics by temperature and saturation state. Am. J. Sci. 1999, 299, 257-288. [CrossRef]

77. Power, I.M.; Wilson, S.A.; Dipple, G.M. Serpentinite Carbonation for $\mathrm{CO}_{2}$ Sequestration. Elements 2013, 9 , 115-121. [CrossRef]

78. Ulven, O.; Beinlich, A.; Hövelmann, J.; Austrheim, H.; Jamtveit, B. Subarctic physicochemical weathering of serpentinized peridotite. Earth Planet. Sci. Lett. 2017, 468, 11-26. [CrossRef]

79. Piccardo, G.B.; Rampone, E.; Romairone, A.; Scambelluri, M.; Tribuzio, R.; Beretta, C. Evolution of the Ligurian Tethys: Inference from petrology and geochemistry of the Ligurian Ophiolites. Per. Mineral. 2001, 70, 147-192.

80. Boulart, C.; Chavagnac, V.; Monnin, C.; Delacour, A.; Ceuleneer, G.; Hoareau, G. Differences in gas venting from ultramafic-hosted warm springs: The example of Oman and Voltri Ophiolites. Ofioliti 2013, 38, 143-156.

81. Hartmann, J.; Jansen, N.; Dürr, H.H.; Kempe, S.; Köhler, P. Global $\mathrm{CO}_{2}$-consumption by chemical weathering: What is the contribution of highly active weathering regions? Glob. Planet. Chang. 2009, 69, 185-194. [CrossRef]

82. Hartmann, J.; Moosdorf, N. The new global lithological map database GLiM: A representation of rock properties at the Earth surface. Geochem. Geophys. Geosyst. 2012, 13, Q12004. [CrossRef]

83. Schopka, H.H.; Derry, L.A.; Arcilla, C.A. Chemical weathering, river geochemistry and atmospheric carbon fluxes from volcanic and ultramafic regions on Luzon Island, the Philippines. Geochim. Cosmochim. Acta 2011, 75, 978-1002. [CrossRef]

84. Pearson, K. Notes on regression and inheritancein the case of two parents. Proc. R. Soc. Lond. 1895, 58, 240-242.

85. Wessa, P. Multivariate Correlation Matrix (v1.0.11) in Free Statistics Software (v1.2.1), Office for Research Development and Education. 2016. Available online: http://www.wessa.net/Patrick.Wessa/rwasp_pairs. wasp/ (accessed on 2 April 2019).

86. Guo, S.; Wang, J.; Xiong, L.; Ying, A.; Li, D. A macro-scale and semi-distributed monthly water balance model to predict climate change impacts in China. J. Hydrol. 2002, 268, 1-15. [CrossRef]

87. Legesse, D.; Vallet-Coulomb, C.; Gasse, F. Hydrological response of a catchment to climate and land use changes in Tropical Africa: Case study South Central Ethiopia. J. Hydrol. 2003, 275, 67-85. [CrossRef]

88. Jiang, T.; Chen, J.D.; Xu, C.; Chen, X.; Chen, X.; Singh, V.P. Comparison of hydrological impacts of climate change simulated by six hydrological models in the Dongjiang Basin, South China. J. Hydrol. 2007, 336, 316-333. [CrossRef] 
89. Lin, Y.; Wen, H.; Liu, S. Surface runoff response to climate change based on artificial neural network (ANN) models: A case study with Zagunao catchment in Upper Minjiang River, Southwest China. J. Water Clim. Chang. 2019, 10, 158-166. [CrossRef]

90. Strefler, J.; Amann, T.; Bauer, N.; Kriegler, E.; Hartmann, J. Potential and costs of carbon dioxide removal by enhanced weathering of rocks. Environ. Res. Lett. 2018, 13, 034010. [CrossRef]

91. Dilek, Y.; Robinson, P.T. (Eds.) Ophiolites in Earth History; Geological Society Special Publication 218; Geological Society of London: London, UK, 2003; p. 723.

(C) 2019 by the authors. Licensee MDPI, Basel, Switzerland. This article is an open access article distributed under the terms and conditions of the Creative Commons Attribution (CC BY) license (http://creativecommons.org/licenses/by/4.0/). 